\title{
HABITUS, REFLEXIVIDADE E NEO-OBJETIVISMO NA TEORIA DA PRÁTICA DE PIERRE BOURDIEU*
}

\section{Gabriel Peters}

\section{Introdução}

* Agradeço aos colegas do Núcleo de Pesquisa em Filosofia das Ciências Sociais (SocioFilo) do Instituto de Estudos Sociais e Políticos da Universidade do Estado do Rio de Janeiro (Iesp/Uerj). Também tive oportunidades valiosas de discussão das questões debatidas no presente texto em minhas participações nos grupos de trabalho sobre teoria social e teoria sociológica que ocorrem periodicamente nos encontros da Anpocs e da Sociedade Brasileira de Sociologia. Gostaria, por fim, de dedicar o artigo a três amigos e mentores intelectuais que insistiram, cada um à sua singularíssima maneira, para que eu pensasse um pouco menos com e um pouco mais contra Bourdieu: Frédéric Vandenberghe, João Daniel Lima e Luís de Gusmão. Minha gratidão não me exime da total responsabilidade pelo que vai adiante.
A tentativa de superação da dicotomia objetivismo/subjetivismo está na raiz do quadro teórico-metodológico de análise da vida social formulado por Pierre Bourdieu. Buscando integrar as ferramentas analíticas legadas por ambos os tipos de enfoque e escapar, ao mesmo tempo, às suas limitaçōes, o sociólogo francês desenvolveu uma abordagem praxiológica cujo cerne é a relação dialética entre condutas individuais propelidas por disposiçōes socialmente adquiridas e reunidas em um habitus, de um lado, e estruturas objetivas ou "campos" de relações entre agentes diferencialmente posicionados e empoderados, de outro. No entanto, a despeito de sua intenção de transcendência da oposição entre modalidades objetivistas e subjetivistas de conhecimento do social, sua abordagem tem sido frequentemente retratada por diversos críticos como uma versão sofisticada de neo-objetivis- 
mo e não como uma teoria sintética satisfatória da relação agência/estrutura.

O presente trabalho busca avaliar o sentido desta crítica, argumentando que ela é parcialmente justificada, embora tenha comumente assumido roupagens simplistas, incapazes de reconhecer a sutileza e a complexidade da sociologia bourdieusiana. A fonte primeira do neo-objetivismo na obra de Bourdieu encontra-se em sua ênfase, valiosa porém unilateral, sobre o caráter tácito ou "pré-reflexivo" da operação do habitus, ênfase que o leva a uma teorização negligente quanto à significação agêntica da consciência reflexiva ou "discursiva" do ator (Giddens, 2003, p. 440). No limite, esta inflexão analítica tem por consequência o desenvolvimento de um instrumental teórico que oferece, mais do que uma alternativa a modalidades objetivistas de explicação sociológica, uma espécie de operacionalização das mesmas (Alexander, 1995, p. 136).

O propósito aqui, pois, não será apenas o de apontar para a inflexão neo-objetivista da praxiologia estrutural de Bourdieu - um procedimento que, em si mesmo, não chega a ser dos mais originais, embora tampouco dos mais produtivos -, mas sobretudo o de contribuir para um diagnóstico mais preciso das origens teórico-metodológicas dessa inflexão e dos percursos argumentativos pelos quais ela pode ser corrigida. $\mathrm{O}$ pressuposto da discussão encetada será, naturalmente, o de que qualquer reflexão sobre o projeto de uma teoria pós-bourdieusiana das práticas sociais tem de partir necessariamente de um balanço crítico detido dos aspectos positivos e negativos do legado sociológico do mestre francês.

\section{Objetivismo e subjetivismo}

A intenção de investigar a complexa relação entre as dimensões subjetiva e objetiva da vida social manifesta-se na afirmação de Bourdieu segundo a qual a tarefa da sociologia consiste em "descobrir as estruturas enterradas de maneira mais profunda nos diversos mundos sociais que compõem o universo societário, bem como os 'mecanismos' que tendem a assegurar sua reprodução ou transformação" (Bourdieu, 1989, p. 7), levando-se em consideração que esse universo existe sob duas formas articuladas: objetivamente como "campo" e subjetivamente como habitus. A noção de campo refere-se a espaços objetivos de relaçôes entre agentes diferencialmente posicionados segundo uma distribuição desigual de recursos materiais e simbólicos, isto é, de capitais múltiplos que operam como meios socialmente eficientes de exercício do poder. O conceito de habitus aponta, por sua vez, para esquemas simbólicos subjetivamente internalizados de geração e organização da atividade prática dos agentes individuais, esquemas que tomam a forma de disposições mentais e corporais, isto é, modos potenciais socialmente adquiridos e tacitamente ativados de agir, pensar, sentir, perceber, interpretar, classificar e avaliar.

A imensa dificuldade em se capturar analiticamente a relação dialética entre estas duas esferas entrelaçadas de existência da sociedade está vigorosamente refletida na "mais fundamental e mais perniciosa [...] de todas as oposiçôes que dividem artificialmente as ciências sociais" (Bourdieu, 1990b, p. 26), qual seja, o confronto entre subjetivismo e objetivismo na análise da conduta humana e da vida social. As manifestaçóes de tais modos antípodas de conhecimento na filosofia e no pensamento antropológico e sociológico seriam múltiplas e, além disso, periodicamente ressuscitadas sob formas falsamente originais mesmo após "terem sido destruídas mil vezes no curso da história científica" (Bourdieu e Wacquant, 1992, p. 179).

Analisando o contexto histórico e intelectual específico de formação e maturação do pensamento sociológico de Pierre Bourdieu, verificamos que a oposição entre "física social" e "fenomenologia social" (Idem, p. 135) que a sua obra intenta superar teve como referência primeira o embate teórico, presente no campo intelectual francês nos anos que se seguiram à Segunda Guerra, entre o existencialismo sartriano e o estruturalismo, sobretudo tal como formulado por Lévi-Strauss no âmbito da antropologia, a partir do modelo da linguística estrutural de Saussure e Jakobson. Enquanto Sartre emprestava forte ênfase a uma suposta liberdade irrevogável da ação humana e aos poderes da subjetividade individual como motor criativo de produção da história, os paladinos do estruturalismo, 
com seu enfoque fortemente determinista e objetivista, acentuavam as determinaçōes inconscientes das representaçōes e/ou condutas individuais. A rigor, esse conflito já sinalizava a derrocada da hegemonia da fenomenologia existencialista de Sartre na academia francesa diante da estrondosa ascensão do estruturalismo como uma espécie de superpoderoso paradigma multidisciplinar sustentado por uma tetrarquia de gurus intelectuais de diferentes campos das ciências humanas: Lévi-Strauss na antropologia, Lacan na psicanálise, Foucault na historiografia (ainda que de uma espécie singular, "arqueológica") e Althusser no terreno marxista, cada um dos quais ofereceu sua contribuição para a violenta demolição do existencialismo, não apenas na roupagem hipersubjetivista original de $O$ ser e $o$ nada, mas também na versão marxificada que Sartre apresentou no seu outro tijolaço - Crítica da razão dialética [1956]:

Lévi-Strauss malhou o eurocentrismo de Sartre; Lacan denunciou o mito da unidade e autonomia do ego (o para-si, fundido mas não abolido nos "grupos em fusão" da violência revolucionária); Althusser fustigou a filosofia do sujeito, a herança hegeliana do existencialismo; e a sentença retumbante de Sartre "o existencialismo é um humanismo" não resistiu à desmoralização dos humanismos filosóficos empreendida por Foucault (Merquior, 1981, p. 194).

Em face desse contexto intelectual formativo, o modelo estruturalista de análise, com sua recusa do subjetivismo implicado no retrato existencialista da conduta e experiência humanas, também marcou de maneira bastante significativa os primeiros trabalhos de investigação etnológica de Bourdieu na sociedade argelina. Não obstante, partindo da orientação estruturalista, ele pôde confrontar os limites desta abordagem e forjar uma maquinaria analítica própria e original, inspirada pela tentativa de resgatar o exame dos interesses estratégicos e das competências práticas cotidianamente mobilizadas pelos agentes sociais, até então concebidos, segundo sua leitura, como meros epifenômenos de estruturas simbólicas inconscientes (ou, alterna- tivamente, como executores conscientes de regras coletivas explicitamente formuladas) no enfoque levi-straussiano.

Compreendido como uma manifestação particular do modo de conhecimento social objetivista, o estruturalismo de Saussure e Lévi-Strauss, segundo a perspectiva bourdieusiana, compartilha com outras manifestações desse tipo de abordagem (por exemplo, o estrutural-funcionalismo durkheimiano ou certa teleologia histórica marxista) o sensato reconhecimento da existência de padröes de conduta e sistemas de relaçôes que se reproduzem independentemente da intencionalidade e da consciência de quaisquer dos atores individuais que compõem uma dada formação societária. A ruptura teórica com as concepçōes subjetivas que organizam a experiência de senso comum dos agentes é saudada por Bourdieu como um passo epistêmico necessário: a) à persecução investigativa das condições sociogenéticas de possibilidade de tal conhecimento e experiência do mundo social como horizonte tácito e imediatamente familiar da conduta individual, tal como retratado nas descrições fenomenológicas da "atitude natural" (Husserl); b) à análise das coaçôes estruturais e dos efeitos sociais emergentes das práticas individuais que escapam à consciência e à vontade dos atores. A postura exterior e distanciada do método objetivista de observação científico-social, visando à superação de toda a sorte de limitações sócio-históricas que incidem sobre as notiones vulgares experiencialmente ancoradas que integram a visão de mundo de qualquer agente particular posicionado no universo social, busca decodificar "a partir de cima", por assim dizer, "a partitura não escrita de acordo com a qual as ações dos agentes, cada um dos quais acredita estar improvisando sua própria melodia, estão organizadas" (Bourdieu, 1983b, p. 70).

O procedimento metodológico de ruptura com as pré-noçôes espontâneas de senso comum que tão bem caracteriza o modo de conhecimento social objetivista, de Marx e Durkheim a Saussure e Lévi-Strauss, constitui, entretanto, uma ferramenta necessária porém não suficiente para uma investigação dos mecanismos por meio dos quais o mundo social perdura em sua existência. Abordando fenômenos e formações sociais como dotados 
de estruturas exteriores aos agentes individuais, estruturas empiricamente constatáveis sob a forma de padrões de conduta e/ou sistemas de relações, as abordagens objetivistas interrompem precocemente seu trabalho na fase do registro de tais regularidades ou propriedades estruturais, privando-se assim do diagnóstico dos princípios ou mecanismos agênticos capazes de responder pela geração e reprodução histórica dos padrões societários observados. Nesse sentido, na ausência do exame dos verdadeiros motores ou matrizes subjetivas de conduta através das quais a agência dos atores é produzida e organizada de modo a engendrar a existência de regularidades institucionais, as perspectivas objetivistas são espuriamente levadas a passar da hipótese do coletivo à sua hipóstase, a confundir "o modelo da realidade" com "a realidade do modelo", reificando abstrações conceituais como "sociedade", "classe" ou "modo de produção", isto é, concebendo-as como entidades autônomas capazes de "agir" à maneira de agentes históricos concretos. No limite, tais abordagens terminam por caracterizar as formações sociais humanas como entidades ontológicas sui generis com leis autônomas de funcionamento e evolução/desenvolvimento, entidades cujos processos reprodutivos e transformativos obedeceriam à operação de fatores causais profundos que independeriam completamente $\mathrm{da}$ consciência e da vontade dos atores, tomadas então como fatores irrelevantes para a explicação desses processos (Bourdieu, 1990a, pp. 150-151).

Opondo ao modelo objetivista um método analítico que ele denomina "praxiológico", Bourdieu afirma que as importantes aquisiçōes teóricas resultantes daquele modelo não devem ser anuladas, mas conservadas e ultrapassadas, "integrando o que esse conhecimento teve de excluir para obtê-las" (1983b, p. 48), isto é, o fato de que o mundo social também é fundamentalmente constituído de "vontade e representação", para tomar de empréstimo as palavras de Schopenhauer. Trata-se então de recuperar o papel causal, na reprodução do mundo social, dos estoques subjetivos de representaçōes/ significados mundanos e de competências/habilidades práticas que os indivíduos mobilizam na interpretação dos seus universos de atuação e investem cronicamente na produção de suas condutas.
A ênfase em tal dimensão subjetiva da vida social é fundamental para evitar-se a armadilha objetivista da reificação, isto é, a naturalização do caráter objetivado das estruturas e instituições sociais, o que implica postular, ao contrário, que tais entidades coletivas só existem através da reprodução e orquestração contínuas das práticas históricas de indivíduos concretos.

Naturalmente, a rica descrição dos "estoques de conhecimento", "sistemas de tipificação e relevância" (Schutz), procedimentos interpretativos e habilidades cognitivas, expressivas, interativas e práticas competentemente mobilizadas pelos atores sociais no curso ininterrupto da vida cotidiana constitui o legado mais significativo das abordagens de inspiração fenomenológica, etnometodológica e simbólico-interacionista (Peters, 2011a), legado reconhecido e apreciado por Bourdieu (Bourdieu e Wacquant, 1992, p. 73). Não obstante, se, por um lado, ele se aproxima de tais perspectivas ao caracterizar as estruturas sociais objetivas não como padrões formais estáticos ou entidades ontológicas autônomas, mas em termos de sua constituição processual contínua, dos modos pelos quais elas são historicamente reproduzidas ou transformadas pelas práticas de agentes hábeis, o autor francês busca também capturar as fontes sociogenéticas (e, portanto, social e historicamente variáveis) de tais habilidades cognitivas e agenciais:

Tanto os fenomenólogos, responsáveis pela explicitação dessa primeira experiência do mundo como algo evidente, quanto os etnometodólogos, cujo projeto consiste em descrevê-la, não dispõem dos meios para explicá-la: ainda que tenham razão de lembrar, contra a visão mecanicista, que os agentes sociais constroem a realidade social, eles omitem a questão da construção social dos princípios de construção dessa realidade empregados pelos agentes nesse trabalho de construção (Bourdieu, 2001c, p. 212).

A ênfase no caráter socialmente aprendido das disposições práticas e esquemas simbólico-cognitivos que impulsionam e capacitam os atores a intervir no curso da vida societária tem como implicação a impossibilidade de se tomar como ta- 
refa exclusiva da ciência social a produção de um relatório fenomenológico de explicitação do conhecimento de senso comum, ou seja, a redução das construções sociológicas a "construções de segundo grau, isto é, construçōes das construçōes feitas pelos atores na cena social" (Schutz, 1962, p. 26). Isto porque a experiência simbolicamente mediada do mundo societário como dotado de imediata evidência e necessidade excluiria, por definição, o inquérito reflexivo acerca de suas circunstâncias específicas de possibilidade. Além disso, a análise das condiçōes sociais de produção das estruturas subjetivas de motivação e conhecimento que orientam tacitamente a experiência que os agentes têm de seus mundos da vida leva à tese de que estas estruturas subjetivas variam sistematicamente conforme variam aquelas condiçôes. Tal variabilidade seria resultante não apenas das diferenças entre contextos sócio-históricos diversos como também das diversas posiçôes diferenciais ocupadas pelos indivíduos em um mesmo espaço social, mais precisamente em função das coações estruturais que tais posiçōes exercem sobre os universos representacionais dos agentes, dado que os "pontos de vista" sobre o mundo societário são sempre "vistas de um ponto" determinado desse mesmo mundo. Por fim, a investigação da sociogênese das disposições práticas e esquemas interpretativos dos atores torna possível captar com maior precisão os "significados objetivos" de suas condutas, isto é, as contribuiçōes funcionais não intencionadas e não conscientes que suas práticas oferecem à reprodução das configuraçôes macrossociais objetivas onde esses indivíduos atuam (Bourdieu, 1979a, p. 73; 1983b, p. 15).

\section{A praxiologia estrutural como estratégia de síntese}

Dessa forma, podemos observar que, na arquitetura do modelo teórico-metodológico de Bourdieu, o acervo das ferramentas conceituais e explicativas mais úteis legadas pelos modos objetivista e subjetivista de análise passa a ser aproveitado em um quadro de referência novo, que toma ambas as maneiras de investigação como "momentos" de um método de pesquisa construído justamente para capturar a relação histórico-dialética entre as trajetórias biográficas dos atores individuais e a reprodução/transformação histórica de estruturas coletivas, tal como essa relação é corporificada em práticas sociais. Recuperando a noção de prática formulada por Marx nas suas Teses sobre Feuerbach, nas quais o Mouro afirma que "toda a vida social é essencialmente prática" (Marx, 2000, p. 113), Bourdieu edifica seu esquema teórico-sociológico em torno dessa categoria, tomada como o modo mais característico da existência social humana, no qual estão relacionadas e unificadas as diversas instâncias fenomênicas tradicionalmente referidas pelas clássicas dicotomias da teoria social e da filosofia, como indivíduo/sociedade, ação/estrutura, material/ideal, mente/corpo, sujeito/objeto, entre outras (Parker, 2000, p. 42).

$\mathrm{Na}$ tentativa de tecer um corpo de hipóteses e conceitos capaz de captar acuradamente a especificidade da(s) lógica(s) da(s) prática(s) levada(s) a cabo pelos atores sociais, bem como a relação dessas práticas com seus contextos estruturais de ocorrência, Bourdieu faz uso criativo de uma diversidade de instrumentos conceituais e insights socioteóricos colhidos de outras abordagens (Marx, Weber, Durkheim, Mauss, Bachelard, Cassirer, Saussure, Chomsky, Lévi-Strauss, Panofsky, Husserl, Heidegger, Merleau-Ponty, Austin, "segundo" Wittgenstein, Goffman, entre outros) e envereda por um projeto teórico que ele caracteriza pelo rótulo de "estruturalismo construtivista" ou "construtivismo estruturalista" (1990a, p. 151). Vejamos como ele mesmo explica sucintamente essa autodesignação:

Por estruturalismo, ou estruturalista, quero dizer que existem, no próprio mundo social e não apenas nos sistemas simbólicos - linguagem, mito, etc. -, estruturas objetivas, independentes da consciência e da vontade dos agentes, as quais são capazes de orientar ou coagir suas práticas e representaçōes. Por construtivismo, quero dizer que há, de um lado, uma gênese social dos esquemas de percepção, pensamento e ação que são constitutivos daquilo que chamo de habitus e, de outro, das estruturas sociais, em particular do que chamo de campos e grupos, e particularmente do que se costuma chamar de classes sociais ${ }^{1}$ (Idem, p. 149). 
De um lado, as estruturas objetivas que o sociólogo constrói no momento objetivista, descartando as representações subjetivas dos agentes, são o fundamento das representações subjetivas e constituem as coações estruturais que pesam nas interaçōes; mas, de outro lado, essas representações também devem ser retidas, sobretudo se quisermos explicar as lutas cotidianas, individuais ou coletivas, que visam transformar ou conservar essas estruturas. Isso significa que os dois momentos, o objetivista e o subjetivista, estão numa relação dialética (Idem, p. 152).

Como instrumento heurístico de orientação à pesquisa de universos sócio-históricos diversificados, a teoria da prática de Bourdieu está ancorada na tese da existência de uma inter-relação causal entre as matrizes socialmente adquiridas de produção da conduta individual ( habitus), de um lado, e as propriedades estruturais dos contextos de socialização, atuação e experiência dos agentes (campos), de outro. Não obstante, sua abordagem não abre mão do caráter metodologicamente ordenado e até mesmo hierarquizado do uso das ferramentas analíticas próprias aos momentos objetivista e subjetivista, conferindo precedência teórica ao primeiro desses estágios sobre o segundo. Nos termos da distinção metodológica clássica entre Erklären e Verstehen, explicação causal e entendimento interpretativo, isto implica que, na visão do autor francês, a compreensão empática ou hermeneuticamente fundada do sentido subjetivo de uma dada conduta, tal como experienciado e representado pelo próprio agente, jamais poderia constituir o caminho heurístico primeiro para sua explicação causal. Ao contrário, seria somente a reconstrução do campo de relações objetivas em que um dado ator se insere como uma posição e perfaz uma trajetória o que constituiria o procedimento analítico que permite o acesso à sua experiência subjetiva e aos móbeis internos de suas açôes (Peters, 2011b). Trata-se, por assim dizer, de iniciar a investigação sempre pela floresta de modo a compreender as árvores, nunca realizando o percurso inverso. ${ }^{2}$

Segundo Bourdieu, é na relação dialética entre habitus e campo - mas em uma dialética que co- meça sempre pelo campo - que se encontra o princípio da gênese das práticas sociais que articulam inextricavelmente os polos da ação e da estrutura, ou do "sentido subjetivo" e das "relaçóes objetivas", para utilizarmos as clássicas expressões de Weber e Marx respectivamente. $\mathrm{Na}$ maior parte das situaçôes empíricas pesquisadas por Bourdieu, essa relação manifesta-se sob uma roupagem de "cumplicidade ontológica", permitindo compreender como a conduta social pode se ajustar objetivamente a determinados fins sem que estes tenham sido explícita e conscientemente visados pelos atores. $\mathrm{O}$ ajuste dar-se-ia por meio da operação tácita ou "pré-reflexiva" de um habitus socialmente estruturado (inculcado a partir de uma trajetória experiencial percorrida ao longo de uma ou mais posiçôes em uma estrutura objetiva de relaçôes) e estruturante (pois tende a reproduzir as estruturas que o constituíram quando mobilizado recursivamente nas ações dos indivíduos). É ao enfatizar esse aspecto dinâmico da vida social que ele concebe, como foi visto, sua perspectiva teórica como um estruturalismo genético ou construtivista, centrado na relação entre as estruturas sociais objetivas distribuídas no espaço social (campos) e as estruturas subjetivas de orientação prática (habitus) que as atualizam ou as transformam no fluxo das contínuas lutas históricas $^{3}$ entre os diversos agentes do mundo societário.

Além da tendência (como tal, historicamente reversível) à reprodução de práticas sociais e relaçôes de poder, a circularidade do habitus permite compreender sua existência como mediação causal entre o individual e o social, como princípio gerador, socialmente gerado, de práticas e representaçôes, "estrutura estruturada predisposta a funcionar como estrutura estruturante" das mesmas estruturas que o estruturaram (Bourdieu, 1983b, p. 61). Esta historicidade circular explica também a relação de tácita familiaridade (o mundo social como taken for granted, na expressão de Schutz) que os atores experienciam na sua realidade cotidiana, experiência "dóxica" (Husserl) de familiaridade que as abordagens fenomenológicas tematizam e descrevem com acurácia, negligenciando, entretanto, a análise de suas condições sócio-históricas de possibilidade, isto é, "a coincidência entre as estruturas objetivas e as estruturas internalizadas que provê a ilusão da 
compreensão imediata" (Bourdieu, 1990b, p. 26; ver também Ortiz, 1983, e Miceli, 2001). Nesse sentido, a realidade social não é percebida por Bourdieu apenas como exterioridade (à maneira de Durkheim) ou interioridade (à maneira da sociologia fenomenológica de Schutz), mas simultaneamente como exterioridade objetiva e interioridade subjetiva, ou ainda - se quisermos dinamizar e dialetizar este retrato, prestando de quebra uma homenagem aos famosos (ou infames) malabarismos verbais do mestre francês - como exterioridade objetiva subjetivamente interiorizada e interioridade subjetiva objetivamente exteriorizada.

\section{O habitus como mediaçáo tácita entre agência e estrutura}

"O duplo processo de interiorização da exterioridade e exteriorização da interioridade" (Bourdieu, 1983b, p. 47) - ou, em outros termos, a "cumplicidade ontológica" (Bourdieu, 1988a, p. 52) estabelecida entre estruturas objetivas e subjetivas - torna possível que as diversas condutas sociais sejam objetivamente orientadas para determinados fins sem que estes tenham sido explicitamente visados pelos indivíduos que as realizam, bastando que eles atualizem seus habitus de maneira prático-intuitiva (daí a referência a um sens pratique) quando exigidos nas diferentes situações de sua existência social. ${ }^{4} \mathrm{O}$ conceito de habitus permitiria compreender como as condutas levadas a cabo pelos atores tendem a se adaptar estrategicamente às condiçôes objetivas de suas ações, não sendo essas, no entanto, fruto de um cálculo racional e deliberado (as condições para o cálculo quase nunca seriam dadas na prática), da obediência consciente a regras explicitamente definidas ou de uma determinação mecânica e automática por causas coletivas inconscientes, mas sim de um processo em que os atores atualizam continuamente as intuições tácitas de um sentido prático adquirido a partir de sua experiência societária, ou, mais precisamente, da exposição continuada e recorrente a condições semelhantes de ação (para mais detalhes, ver Peters, 2010).

A caracterização do habitus como um "sentido prático" também tem a virtude heurística de avançar uma compreensão não dualista da relação mente/corpo, refletida na duplicidade semântica da noção de "sentido", simultaneamente referente ao aparato sensorial por meio do qual nossos corpos experienciam sua imersão na realidade social e aos instrumentos simbólico-interpretativos que imbuem essa experiência de significados subjetivos. Além de propiciar um caminho fecundo para a captura de tal articulação entre o sentido sensóreo e o sentido significante, a insistência no modo pré-reflexivo de ajustamento criativo dos habitus às suas circunstâncias sociais de funcionamento implica uma rejeição vigorosa, na esteira das contribuiçôes de autores tão diversos como Heidegger, Merleau-Ponty, Wittgenstein e até mesmo Dewey, dos retratos excessivamente intelectualistas das ações e motivações humanas que resultariam da "falácia escolástica", procedimento no qual os modelos analíticos que o/a cientista social constrói para dar conta das propriedades das práticas são projetados nas mentes ou consciências dos agentes e tomados como as causas reais, empiricamente operantes, dessas mesmas práticas.

O "juridicismo estruturalista" consistiu, no trabalho de Bourdieu, no primeiro exemplo desse modo falacioso de caracterização das motivações subjetivas das práticas individuais por meio da projeção inconsciente do sujeito cognoscente (sujet connaissant) no sujeito atuante (sujet agissant). Em discussōes mais recentes, Bourdieu se dedicou a apontar para o mesmo tipo de erro em seus anátemas ocasionais contra o intelectualismo da teoria da escolha racional, caracterizando o modelo do agente humano avançado por essa abordagem como "uma espécie de monstro com a cabeça do pensador pensando a sua prática de modo reflexivo e lógico montada sobre o corpo de um homem de ação engajado na ação" (Bourdieu e Wacquant, 1992, p. 123).

A concepção bourdieusiana da relação entre agência e estrutura está, portanto, intimamente atada à sua visão do caráter fundamentalmente tácito da operação dos motores subjetivos da conduta humana. O problema é que não é preciso superestimar o grau de autotransparência motivacional dos atores leigos para reconhecer que a ênfase de Bourdieu sobre o funcionamento tácito do habitus, 
ainda que valiosa, leva-o a negligenciar o relativo controle reflexivo e consciente que aqueles podem exercer sobre suas próprias disposições práticas de conduta. No que parece ser, à primeira vista, um paradoxo, a sociologia reflexiva de Bourdieu é tremendamente cética quanto à possibilidade de que os próprios atores tematizem reflexivamente as propriedades de seus habitus e transformem-nas criativamente em certa medida. Dentro dos quadros da teoria bourdieusiana da prática, tais processos de autorreflexão e autotransformação reflexiva só poderiam ocorrer, grosso modo, em duas situações: o efeito de hysteresis e o trabalho de auto-objetivação possibilitado pela sociologia.

\section{Reprodução, mudança e o efeito de bysteresis}

A articulação entre agência e estrutura delineada na praxiologia relacional de Bourdieu é infensa ao postulado de que as condutas dos agentes humanos podem ser diretamente deduzidas de estímulos exteriores instantâneos derivados de seus ambientes de atuação, dado o papel fundamental do habitus, como repositório sedimentado de influências societárias passadas, na configuração de ações no presente, repositório que, como tal, possui uma autonomia relativa vis-à-vis as coações externas imediatamente vigentes em um determinado contexto de comportamento social. Por outro lado, a designação da prática como o produto da relação habitus/campo, ao escapar da armadilha da caracterização exclusivamente externalista e instantaneísta da ação postulada por certas abordagens, não descamba para o polo unilateralmente internalista na explicação da conduta humana. Isto porque os propulsores subjetivos da conduta internalizados ao longo de uma trajetória biográfica submetida às exigências de determinadas condições sócio-históricas de existência apresentam-se, ante um certo palco ou milieu de açôes e relaçôes societárias, como disposiçôes ou propensões. Estas, por definição, não constituem, por si mesmas, forças suficientes para a parturição de um comportamento, já que sua ativação tem de ser engatilhada por demandas práticas que os mundos sociais exteriores impõem aos atores, ainda que (de novo a circularidade) tais estímulos exteriores à ação só possam ser reconhecidos qua estímulos por indivíduos cognitivamente aparelhados para percebê-los.

A designação da articulação dialética entre habitus e campo como princípio histórico-genético das práticas societárias é sensível à variabilidade dos caracteres específicos de cada uma dessas instâncias, bem como dos tipos multiformes de relação que podem ser estabelecidas entre as mesmas. É através dessa tese que Bourdieu visa escapar à frequente acusação de "reprodutivismo" dirigida à sua teoria da prática, pois a tendência à reprodução das estruturas sociais objetivas por meio da coordenação espontânea e não intencionada de uma multiplicidade de açōes individuais subjetivamente impulsionadas por habitus semelhantes ou reciprocamente "harmonizados" (por exemplo, na relação cúmplice entre dominantes e dominados que caracteriza a "violência simbólica") não é tida por ele como um caso sociológico universal, mas sim como uma condição histórica particular, proveniente da identidade ou homologia estrutural entre as circunstâncias de constituição e as circunstâncias de operação do habitus. Este também poderia experimentar situações críticas de discrepância nos momentos de desaparecimento de tal cumplicidade ontológica entre o universo subjetivo do agente ("um mundo dentro do mundo" [Bourdieu, 1990b, p. 56]) e o universo objetivo que o circunda.

O caráter relacional das análises de Bourdieu não é abandonado, portanto, nos casos de hysteresis (Bourdieu e Passeron, 1975, p. 69; Bourdieu, 1979a, p. 89) em que a ativação das disposições encarnadas no habitus é exigida em contextos diferentes daqueles que o produziram, circunstâncias sócio-históricas de desajuste entre as condiçôes de produção e as condições de funcionamento do $h a-$ bitus que constituem a principal fonte de mudança social discutida na obra de Bourdieu, em particular na sua análise do Maio de 68 na França (Bourdieu, 1988b, cap. 5). Do ponto de vista de suas concepçôes acerca das engrenagens que movem a conduta individual, essa análise também é elucidativa, pois a quebra da cumplicidade ontológica entre expectativas e disposições subjetivas, de um lado, e condições e efeitos objetivos do milieu societário, de outro, abre espaço para que a conduta "natural- 
-performativa" do habitus possa ser substituída por motivações "hipotético-reflexivas" (os termos são de Habermas) demandadas por aquela dissonância. Esta última estimularia, assim, a recuperação discursiva e a crítica explícita do que até então tinham sido assunções doxicamente aceitas, a transmutação da práxis em logos, a passagem do senso prático à elaboração discursiva e à consideração consciente de alternativas de ação:

A crítica que traz o não discutido à discussão, o não formulado à formulação, tem como sua condição de possibilidade a crise objetiva, a qual, quebrando o laço imediato entre as estruturas subjetivas e as estruturas objetivas, destrói a autoevidência no âmbito prático (Bourdieu, 1979a, p. 169).

Montaigne afirma que compreendeu muito bem "a força do costume quem primeiro inventou essa história de uma mulher que, tendo-se habituado a acariciar e a carregar nos braços um bezerro, desde o nascimento, e o fazendo diariamente, chegou, pela força do hábito, a carregá-lo ainda quando já se tinha tornado um boi” (Montaigne, 1987, p.178). Bourdieu seria o último a negar tal inércia relativa de nossos habitus, tendendo, por vezes, na verdade, a exagerá-la quase tanto quanto o/a autor/a da anedota de Montaigne. Nesse sentido, é óbvio que ele reconhece que o efeito de histerese não acarreta o desaparecimento imediato dos esquemas e disposições próprios aos antigos habitus, agora descompassados em relação às injunções de uma nova estrutura, mas os submete a um confronto dialético com as orientações de conduta fabricadas por uma reflexão consciente dos atores sobre suas próprias práticas, como resposta à defrontação com um ambiente social estruturalmente modificado. Os cursos de ação engendrados por esses processos reflexivos são social e historicamente diversos, podendo não apenas parir a mobilização coletiva para a insurreição social transformativa, como no caso supracitado do movimento de maio de 68, mas também a submissão resignada a condiçôes de existência as mais desfavoráveis, exemplificada na situação do subproletariado argelino na passagem de uma economia tradicional para uma economia capitalista naquele país (Bourdieu, 1979b).

De todo modo, o problema central que nos interessa aqui é que a referência à "crise objetiva" como requisito para o acesso reflexivo do ator a dimensôes outrora inconscientes de seu próprio habitus é signo do fato de que Bourdieu não considera essa possibilidade de acesso um atributo universal do agente humano, mas sim um fenômeno específico a circunstâncias históricas em que os atores são submetidos a efeitos de histerese e forçados a sair, por assim dizer, do "piloto automático". A dependência que a interrupção dos efeitos reprodutivistas do habitus tem dessa mesma "crise objetiva" indica que, ainda que este garanta ao ator uma capacidade inventiva, o caráter criativo desse sistema de disposições não chega, por si só, a constituir uma ameaça à reprodução das estruturas dos campos onde ele viceja, na medida em que essa inventividade funciona dentro de fronteiras objetivas estabelecidas na sua própria gênese e infusos na sua constituição mesma. A prioridade conferida, em termos habermasianos, à "crise sistêmica" sobre a "crise vivida" torna patente que o ator individual não possui, na perspectiva de Bourdieu, um poder causal autônomo de transformação dos pilares fundamentais dos ambientes estruturais onde opera, algo que leva diversos autores a afirmar que, no fim das contas, o pensador francês não ultrapassa o objetivismo, pois subordina teoricamente o polo da agência ao polo da estrutura. A teoria do habitus ofereceria, a rigor, não "uma alternativa à explicação socioestrutural", mas a sua operacionalização (Alexander, 1995, p. 136).

De qualquer forma, mesmo o reconhecimento, por parte de Bourdieu, de que o conceito de habitus se refere a um princípio causal de formas particulares (embora "particularmente freqüentes" [Bourdieu, 2001c, p. 177]) de ação socialmente situada, o qual coexiste no mundo societário com outras modalidades de propulsão subjetiva da conduta operantes em contextos diferenciados (tais como a adequação racional-calculista de meios a fins baseada na consideração consciente de alternativas possíveis de ação ou a obediência consciente a normas de conduta explicitamente estatuídas), é insuficiente para evitar seu deslize teórico-metodológico em 
direção a "um objetivismo de segunda ordem". Sua concepção quanto à precedência ontológica e metodológica do nível objetivo sobre o nível subjetivo da realidade social permanece patente na ideia de que, ao menos que tange ao ator leigo, é a desestabilização da cumplicidade ontológica entre as disposiçôes dos agentes e seus ambientes estruturais de atuação/experiência que está na base do surgimento de açōes fundadas sobre deliberações reflexivas. É, assim, negada a possibilidade do processo inverso, isto é, de que o próprio exercício consciente da reflexividade pelos atores acarrete por sua vez uma quebra total ou parcial daquela cumplicidade.

Se Bourdieu pensava os quadros teórico-metodológicos de análise da vida social como instrumentos heurísticos "ontologicamente flexíveis" (Sibeon, 2004, p. 197), ou seja, sensíveis à variabilidade empírica dos processos sócio-históricos (incluindo-se aí os motores subjetivos da conduta), ele deveria ter reconhecido de modo mais consequente no seu repertório conceitual a possibilidade de açôes determinadas, ao menos em parte, pela consciência reflexiva, mesmo que estas fossem tomadas como variedades empíricas raras de comportamento. De qualquer forma, a própria hipótese quanto a esta suposta raridade também está em jogo na crítica ao déficit de reflexividade presente na caracterização bourdieusiana do ator. Não se trata, portanto, apenas da ideia de que um quadro teórico-metodológico de análise da agência humana e da vida social deva possuir flexibilidade ontológica de modo a incluir múltiplos tipos empiricamente possíveis de conduta subjetivamente motivada; o problema é também substantivo e diz respeito ao fato de que "simplesmente não é verdade que o voluntarismo, sob a forma da formação racional de decisōes, do planejamento, da elaboração 'calculada' de estratégias e contraestratégias, refere-se a situações extremas ou raras" (Mouzelis, 1995, p. 112; Crossley, 2001, p. 97).

No que diz respeito à discussão sobre a relação entre consciência reflexiva, reprodução e mudança, podemos concluir enfim que, mesmo se acatássemos a tese de que o papel causalmente determinante da consciência reflexiva do agente depende sempre da quebra sócio-histórica da cumplicidade ontológica entre estruturas subjetivas e estruturas objetivas, teríamos de acrescentar, pace Bourdieu, que, em algum grau, tais situações de quebra são "radicalmente mais freqüentes" (Elder-Vass, 2007, p. 341) no mundo social do que reconhece o sociólogo francês - entre outros motivos porque, como mostrou Lahire (2002) em certo detalhe, mesmo os atores mais intensamente engajados em lutas de campo também são obrigados a atuar em uma pletora de outros contextos sociopráticos de atividade para os quais as disposiçôes de seus habitus podem não estar bem ajustadas. Portanto, as inadequações entre as expectativas subjetivas oriundas do habitus e os resultados das experiências práticas efetivas não se encontram apenas nas situaçōes de crise radical que Bourdieu caracteriza por meio da ideia de efeito de histerese, mas constituem parte e parcela da existência social cotidiana de qualquer ator. ${ }^{5} \mathrm{Se}$, como Bourdieu afirma, tais disjunções práticas entre antecipações mentais tácitas e efeitos mundanos da ação levam o agente não apenas a buscar o auxílio agêntico da consideração consciente de modalidades alternativas de conduta, como também a operar conscientemente sobre si mesmo um trabalho de transformação adaptativa de seu habitus (de modo a torná-lo mais adequado às novas circunstâncias), a interação e, portanto, o condicionamento mútuo entre disposições habituais e reflexões conscientes na produção da ação é um fenômeno bem menos excepcional do que pensa Bourdieu.

\section{A sociologia como arma de reflexividade}

Ainda que o habitus seja o propulsor mais frequente da ação, bem como uma propriedade universal da prática humana, Bourdieu não afasta a possibilidade de condutas causalmente eficazes motivadas por deliberações explicitamente articuladas na mente dos atores, apenas apontando para o fato de que tal forma de comportamento dependeria de circunstâncias sócio-históricas específicas:

[...] o habitus é um princípio entre outros de produção das práticas e, ainda que esteja indubitavelmente em jogo de maneira mais freqüente que quaisquer outros - "Somos empíri- 
cos", disse Leibniz, "em três quartos das nossas açôes" -, não se pode descartar que ele possa ser substituído em certas circunstâncias - certamente em situaçóes de crise que rompem o ajustamento imediato do habitus ao campo por outros princípios, como a computação racional e consciente (Bourdieu, 1990c, p. 108).

Segundo o sociólogo do Béarn, afora o descompasso histórico entre disposiçōes e interesses subjetivos, de um lado, e as probabilidades objetivas de lucro material e/ou simbólico, de outro, a tentativa de obtenção do domínio reflexivo do próprio habitus (ou de parte dele) também pode ser amparada pela própria sociologia quando esta é mobilizada como um ferramental de autossocioanálise, isto é, em um trabalho de investigação autocognoscitiva. Tal trabalho reflexivo pode ter um papel emancipatório ou libertador, em particular nos casos em que ele expõe ao escrutínio crítico disposiçóes e esquemas interpretativos que levam os atores a perceber como legítima (e, assim, a colaborar, ainda que tacitamente, com) a sua própria dominação:

[...] não apenas pode o habitus ser transformado praticamente (sempre dentro de fronteiras definidas) pelo efeito de uma trajetória social levando a condiçôes de vida distintas daquelas iniciais, como também pode ser controlado por meio do despertar da consciência e pela socioanálise (Idem, p. 116).

A empreitada de uma sociologia reflexiva, que Bourdieu propugnava ser sua principal contribuição às ciências sociais, assenta precisamente na possibilidade de que disposições impensadas de pensamento e comportamento possam ser racionalmente controladas ao acederem ao nível da consciência. No âmbito epistemológico, trata-se, na verdade, de uma reatualização propriamente sociológica da noção kantiana de crítica, originalmente concebida como a capacidade de reflexão do pensamento ou razão acerca de seus próprios pressupostos e limites, sendo tais pressupostos e limites historicizados e sociologizados por Bourdieu, isto é, não mais pensados como atributos de um sujeito transcendental, mas como resultantes da inevitável inserção do/a pesquisador/a em uma formação sócio-histórica que emoldura seu modus cognoscendi.

Se transposto da esfera da prática sociocientí fica para o universo social mais amplo e pensado não apenas como preceito metodológico, mas também ético-político, o procedimento da crítica em Bourdieu, além de demonstrar (no rastro do Durkheim de As formas elementares da vida religiosa) o caráter socialmente constituído das capacidades operativas formadoras da sensibilidade e do entendimento dos agentes, ainda une o sentido kantiano de escavação sistemática de pressupostos do pensamento e da ação a um sentido mais afeito ao marxismo, associado ao esforço de desvendamento de modalidades ideologicamente mascaradas de dominação e exploração. Isto porque as categorias de percepção e orientação da conduta que garantem a inteligibilidade do mundo social para os agentes são, na visão do sociólogo francês, as mesmas que os levam a naturalizar e essencializar as assimetrias duráveis de poder que perpassam esse mesmo mundo.

Nesse sentido, a obra de Bourdieu pretende contribuir para a desnaturalização, desbanalização e desessencialização dessas relações de dominação, desnudadas como arbitrariedades históricas contingentes falsamente travestidas como ordenamentos naturais das coisas para a (in)consciência comum. No seu Esboço de autoanálise, ${ }^{6}$ Bourdieu também faz votos de que seus instrumentos sociológicos sejam utilizados como ferramentas de autorreflexão, autognose e autoajuda, compreendendo-se essa última expressão, é claro, no sentido da tradição filosófica clássica de reflexão sobre os modos de aplacar o sofrimento e os caminhos da "boa vida" (Aristóteles) e não daquela indústria bibliográfica contemporânea tão desprezada por um contingente substancial de intelectuais:

[...] nada me deixaria mais feliz do que lograr levar alguns dos meus leitores ou leitoras a reconhecer suas experiências, suas dificuldades, suas indagaçôes, seus sofrimentos, etc. nos meus e a poder extrair dessa identificação realista, justo o oposto de uma projeção exaltada, meios de fazer e viver um pouco melhor aquilo que vivem e fazem (Bourdieu, 2005, p. 135). 
A despeito da diferença de teses e métodos, a referência implícita à psicanálise na noção de socioanálise serve para manifestar o enraizamento moral comum no projeto socrático da autoconsciência como caminho existencial emancipatório, no propósito de expandir o nível da consciência humana para dimensôes determinantes da sua conduta, as quais, se deixadas intocadas por esse esforço reflexivo metodologicamente municiado, permanecem escondidas, reprimidas, inconscientes, dissimuladas. Um Aufklärer como Freud, Bourdieu persegue, no entanto, um inconsciente distinto daquele pensado pelo pai da psicanálise: a matriz socialmente interiorizada de onde florescem as ações, percepçôes e avaliações (inseparavelmente éticas, estéticas e afetivas) que configuram nosso modo de ser no mundo, isto é, nosso habitus.

Se, como afirma Durkheim, "o verdadeiro inconsciente é a história", o/a autoanalista sociologicamente municiado/a pelo pensamento de Bourdieu, trabalhando sob a égide do princípio " $D e$ te fabula narratur", conhece a si mesmo/a como "história feita corpo", personalidade socialmente constituída, ser dotado de um habitus que, em princípio, o possui, mais do que é possuído por ele. A dimensão de desencanto dessa linha de análise é inegável, dado que ela não nos pinta como seres irredutíveis ao mundo, mas mundanos, demasiado mundanos, moldados nos territórios mais íntimos de nossa personalidade por determinações sócio-históricas exteriores a nós, porém objetivadas na nossa subjetividade mesma. A autoanálise sociologicamente armada leva assim às descobertas desconfortáveis e até mesmo dolorosas da objetividade situada no seio da subjetividade, da externalidade no coração da internalidade, da banalidade no que até então fundamentava uma autorrepresentação ilusória de raridade.

Todas essas implicações podem possuir, entretanto, um caráter potencialmente emancipatório sob as lentes de Bourdieu, na medida em que esse esforço sociológico-reflexivo de "anamnese" (Platão), isto é, de recuperação de significações persistentemente atuantes em nós e, ao mesmo tempo, opacas à nossa consciência, constitui uma via de acesso a um trabalho de autorreapropriação. Em uma esfera de realidade onde não estão em operação as leis trans-históricas da natureza, reconhecer as forças que agem sobre nós e, em particular, "dentro" ou "através" de nós, é adquirir uma ferramenta para fazer alguma coisa a respeito, agindo sobre ou contra tais forças. Ao trazer a pretensão "clínica" ou "délfica" para o campo das ciências sociais, Bourdieu propõe a tese de que "a sociologia liberta libertando da ilusão de liberdade" (Bourdieu, 1990a, p. 28). O verbo "libertando", nesse caso, é tudo menos uma repetição pedante e desnecessária, pois comunica a ideia de que a possibilidade de liberdade oferecida pela objetivação dos condicionantes societários do pensamento e da conduta vai além do resignado e impotente "reconhecimento da necessidade" (Spinoza/Hegel). Sendo as "necessidades" operantes no mundo social historicamente constituídas e reproduzidas através das açōes e representaçôes dos atores humanos, o reconhecimento de tais "necessidades" pode dar ensejo ao seu questionamento, combate ou destruição. Ao amplificar a consciência dos determinismos que coagem a conduta social, não apenas daqueles que se exercem sobre os atores a partir de "fora", mas também através dos atores a partir de dentro, subcutaneamente conduzidos, por assim dizer, nos meandros de seus corpos e mentes, Bourdieu pretende oferecer armas eficientes de contra-atuação sobre essas estruturas e mecanismos coativos e contribuir com a consecução de uma margem de liberdade em relação aos mesmos.

A reflexividade aparece, assim, como uma ferramenta passível de transposição do domínio da ciência social para aquele da ética e da política. No plano epistemológico, devido ao "racionalismo aplicado" que herdou de Bachelard, Bourdieu advoga uma leitura "disposicional" do seu quadro teórico-metodológico de análise da vida social, pensado como um programa intelectual voltado à inculcação gradual de um habitus sociocientífico que guie o pesquisador de modo heuristicamente fecundo nas suas investigações de cenários sociais concretos. $\mathrm{O}$ mesmo enfoque disposicional pode ser mantido no caso da transposição do imperativo da reflexividade do plano da metodologia sociológica para o de uma proposta ético-política de autoconsciência e autoconstrução, em função da qual Bourdieu pode ser frouxamente conectado a uma tradição que pensa o conhecimento (do) humano de modo entrelaçado à conduta da 
vida. Na medida em que o cultivo reflexivo de um novo habitus não se reduz à dimensão cognitiva da subjetividade, mas engaja a personalidade inteira, essa tarefa pode ser concebida como um "exercício espiritual" no sentido secular pensado por Pierre Hadot $(1995,2004)$.

Não obstante, vale dizer que a proposta de autolibertação e autotransformação reflexiva por meio da socioanálise não deve ser pensada como uma substituição da ação política por uma orientação ética individualista. A objetivação sociológica de padrões de dominação e violência simbólica, ao apontar para os profundos efeitos cognitivos, morais, emocionais e corpóreos que estas possuem sobre as subjetividades individuais, acarreta consequências inseparavelmente políticas e "existenciais". Se "o pessoal é social” (Bourdieu e Wacquant, 1992, p. 202) e, portanto (feministas, uni-vos!), político, a ética da boa vida se entrelaça à política da Cidade Justa, a "sociologia clínica" torna-se parte de uma "política reflexiva" (Frangie, 2009, p. 213), enquanto o questionamento/luta contra a dominação exterior e interiorizada se torna tanto um ato ético de autoconstrução reflexiva quanto uma manobra política de resistência à dominação.

\section{Recuperando a reflexividade do ator leigo}

A proposta de Bourdieu é, sem dúvida, muito valiosa, mas parece levar longe demais a ideia de que, fora da situação sócio-histórica de hysteresis, apenas a auto-objetivação sociológica permite o acesso reflexivo e consciente do ator (não sociólogo) a certas dimensōes do seu próprio habitus. Assim, as propriedades dos habitus dos agentes leigos só poderiam ser reflexivamente tematizadas por seus próprios possuidores nos contextos "histerésicos" em que houvesse uma disjunção entre as circunstâncias estruturais de parturição e as circunstâncias estruturais de mobilização agêntica de seus sistemas de disposições práticas e esquemas simbólicos internalizados. Tais contextos em que está ausente a cumplicidade ontológica entre estruturas subjetivas e objetivas tendem a ser tidos como social e historicamente excepcionais por Bourdieu e, de todo modo, são mais raramente escrutinados na sua obra do que aqueles em que existe um vínculo sociogenético e um reforço circular entre habitus e campo (Vandenberghe, 2010, p. 290).

Do ponto de vista teórico, o que está em jogo é o status da relação ontológica entre três níveis da realidade societária (Kogler, 1997, pp. 142-143): a) as condiçôes sociais objetivas que conformam os ambientes estruturados em que os indivíduos atuam e que tomam a forma de ordens distributivas de uma pletora de recursos materiais ou simbólicos (formas de capital, diria Bourdieu), ordens que coagem em variados graus os cursos factíveis de ação e as "oportunidades de vida" (Weber) dos agentes; b) as crenças e intenções explicitamente sustentadas pelos atores e conscientemente mobilizadas por estes na produção de seus comportamentos; c) os esquemas simbólico-interpretativos operantes sob a forma de crenças tácitas e "etnométodos" que se referem ao que Bourdieu denomina de habitus. Como vimos, ainda que considere esse último nível sócio-ontológico como o mais frequente e decisivamente determinante na relação dos agentes com seus contextos societários objetivos e, por meio desse relacionamento, na gênese das práticas sociais que desenham o curso da evolução sócio-histórica, Bourdieu não chega a oferecer um estatuto puramente epifenomênico ao nível das orientaçóes subjetivas de conduta explícita e discursivamente mobilizadas pelos atores. Ele efetivamente coloca, no entanto, uma série de restrições à sua eficácia causal.

$\mathrm{Na}$ medida em que o ator leigo não está, como o/a sociólogo/a, armado de um arsenal de técnicas de ruptura com as representaçóes espontâneas do mundo societário, condição metodológica fundamental, segundo Bourdieu, da explicitação científica dos esquemas práticos do habitus, ele não teria como recuperar reflexivamente tais esquemas, em virtude da presença de uma série de coaçōes obstaculizadoras objetivas e subjetivas: a "urgência da prática", que impede que os indivíduos se retirem do mundo social para examiná-lo, a necessidade de dissimulação seja do caráter "interessado" de certas ações (como nos ciclos da dádiva nas sociedades não capitalistas ou nas tomadas de posição estética no campo artístico contemporâneo), seja da arbitrariedade de assimetrias de poder percebidas como legítimas mesmo por aqueles que não são seus beneficiários, ou ainda, 
a própria docta ignorantia que avultaria como característica definidora do habitus, "um modo de conhecimento prático que não abarca o conhecimento dos seus próprios princípios" e que teria dificuldade em pensá-los e nomeá-los, uma vez que eles constituem as condições mesmas de possibilidade do pensar e nomear (Bourdieu, 1979a, p. 19).

A comparação com a abordagem estruturacionista de Giddens (1979, 2003; para uma análise, ver Peters, 2011c; no prelo) pode ser útil para identificar o déficit de reflexividade presente no retrato bourdieusiano do ator. $\mathrm{Na}$ teoria da estruturação, ainda que seja reconhecida a distinção entre conhecimento teórico explícito e conhecimento prático (know how, savoir-faire), bem como a extraordinária importância desse último para a continuidade da vida social, todos os agentes, e não apenas os cientistas sociais, são tidos como inerentemente dotados da capacidade de refletir acerca dos princípios da própria conduta e de atuar eficaz e conscientemente para modificá-los. Assim, uma autonomia relativa é teoricamente concedida não apenas à dimensão do habitus/consciência prática e à instância analítica das condições sociais objetivas, mas também, e independentemente da existência ou inexistência da chamada "cumplicidade ontológica", ao plano da reflexão consciente dos atores, sendo essa vista como capaz de influenciar causalmente cada um daqueles níveis sócio-ontológicos, ao mesmo tempo em que é influenciada por eles.

Tal reflexão permite entrever que a principal fonte do neo-objetivismo de Bourdieu é a ausência de um conceito que possa incluir a consciência reflexiva do ator como um componente fundamental à explicação da agência individual. Embora seja um elemento necessário, o conceito de habitus é claramente insuficiente para uma caracterização heuristicamente mais fecunda dos motores subjetivos da conduta do ator leigo. Como bem observou Crossley (2001, p. 97), a categoria é submetida a uma carga excessiva de trabalho socioanalítico no pensamento de Bourdieu, e a pesada ênfase sobre o caráter tácito e infraconsciente do seu funcionamento parece ser a porta de entrada para uma forma de neo-objetivismo na sua teoria da prática.

Isto fica patente no momento em que Bourdieu reconhece que os agentes atuam "pré-reflexi- vamente" com base em um estoque de disposições práticas e categorias de percepção e orientação que constituem a interiorização das injunções dos seus espaços objetivos de socialização. Nesse sentido, eles/as de fato só podem ser percebidos como "os sujeitos aparentes de açôes que têm a estrutura objetiva como seu sujeito" verdadeiro (Bourdieu e Wacquant, 1992, p. 49). Esse postulado não seria, aliás, afetado pela identificação do encontro dialético entre habitus e campo como o princípio histórico-genético de produção das práticas sociais, pois as propriedades de quaisquer habitus, enquanto interiorizações subjetivas de objetividades, poderiam ser reduzidas às suas condiçôes sociais particulares de produção, sendo o habitus capaz de produzir "pensamentos, percepções e ações" ajustados a tais circunstâncias sócio-históricas e "apenas estes" (Bourdieu, 1990b, p. 55, grifos meus). Dessa forma, aquele encontro pode ser alternativamente lido como ocorrendo não entre um agente e uma estrutura social na qual este está imerso, mas entre duas estruturas: aquela onde o agente foi formado e que está, por assim dizer, sedimentada na matriz de disposições estruturadas do seu corpo e da sua mente - e aquela onde ele está agindo.

A ação seria assim reduzida a uma dialética entre estruturas objetivas, a do passado e a do presente, ainda que tal dialética seja possibilitada apenas pela mediação do habitus como instância de atualização ou presentificação (com o perdão da heideggerianice) dos contextos estruturais de formação do agente no interior dos seus ambientes estruturados de atuação. $\mathrm{Na}$ medida em que Bourdieu atesta que a reapropriação reflexiva de si mesmo, que está na base da possibilidade de autodeterminação racional, só pode ser levada a cabo por meio da escavação sistemática das estruturas sociais objetivadas na subjetividade do agente sob a forma de um habitus, e tendo-se em mente que são pouquíssimas as pessoas que realizaram ou teriam condições de realizar esse trabalho, somos levados a concluir que a imensa maioria dos atores que povoam o mundo social pode ser, assim, fidedignamente caracterizada, na sua perspectiva, como formada por "sujeitos aparentes de ações que têm a estrutura como seu sujeito" (Bourdieu e Wacquant, 1992, p. 49). 


\section{Liçôes de $A$ miséria do mundo}

A sociologia de Bourdieu foi frequentemente acusada de criptonormativismo, isto é, de haver avançado uma teoria da dominação simbólica com óbvias ressonâncias morais e políticas, mas sem estabelecer critérios normativos claros para fundamentar e justificar sua postura hipercrítica em relação ao mundo social (Vandenberghe, 2010, p. 84; Sayer, 2005, p. 16). Como também acontece costumeiramente com Foucault, tal combinação entre uma ausência de ideais normativos explícita ou sistematicamente apresentados, de um lado, e um retrato impiedoso do quão abrangente e profundo é o alcance do poder e da dominação na vida social, de outro, pôde até mesmo levar da imputação de criptonormatividade às acusaçôes mais sérias de cinismo e niilismo (Alexander, 1995, pp. 129, 211; para o caso de Foucault, ver Merquior, 1985).

Ambas as acusações podem ser substancialmente mitigadas à luz do programa ético-político da sociologia reflexiva que acabamos de localizar na sua obra, isto é, do seu projeto de oferecer aos atores leigos ferramentas intelectuais e práticas com as quais eles possam contra-atuar diante dos constrangimentos sócio-históricos que pesam sobre suas condutas, não apenas sob a forma de restrições exteriores às suas iniciativas de ação, mas também de coaçōes que operam "dentro" ou "através" deles, mediadas por suas disposiçōes mentais e corporais interiorizadas via socialização. Entretanto, parece haver um enorme hiato entre o "pessimismo do intelecto" que caracteriza seu retrato teórico substantivo do agente leigo, no mais das vezes quase plenamente identificado às disposiçóes práticas e infraconscientes do seu habitus, e o "otimismo da vontade" embutido na versão ético-política ampliada do programa de uma sociologia reflexiva (ampliada, isto é, para uma população mais abrangente do que aquela dos cientistas sociais). $\mathrm{O}$ único modo pelo qual esse último projeto poderia escapar a uma espécie de contradição autoderrotista seria através do postulado de que os atores leigos já possuem, em princípio, a capacidade de estabelecer algum distanciamento reflexivo (relativo e variável, mas não negligenciável) tanto em relação aos seus habitats exteriores quanto aos seus habitus interiorizados - a capacidade mesma que tornaria o "autoesclarecimento" reflexivo pelo uso da sociologia possível em primeiro lugar.

Nesse sentido, o avanço de uma sociologia reflexiva que mobilize as ferramentas da ciência para prover aos agentes uma empoderadora compreensão das conexôes entre suas biografias singulares e os contextos estruturais mais amplos em que estão embebidos não será diluído, mas fortalecido pelo reconhecimento de que os atores leigos estão de posse de poderes de reflexividade maiores do que Bourdieu estava disposto a admitir em seu esquema teórico. A reintrodução da reflexividade leiga na teoria da prática e a proposta emancipatória de uma sociologia reflexiva podem, assim, ser tomadas como partes complementares de um mesmo exercício.

De certa forma, a articulação entre esses dois projetos chegou a ser inadvertidamente reconhecida por Bourdieu na obra que ele publicou, com um time de colaboradores, sobre múltiplas formas de "sofrimento social" na contemporaneidade: $A$ miséria do mundo (1997). O livro oferece uma manifestação palpável de sociologia reflexiva in actu, um exercício sociocientífico de exploração das articulaçôes entre as situaçôes biográficas de indivíduos particulares e suas localizações estruturais em uma história macrossocial. No entanto, os insights que ele oferece sobre as "misérias de reconhecimento" como modalidades de sofrimento social traem também uma demonstração do alcance da reflexividade dos agentes leigos, inclusive daqueles que ocupam posiçôes mais subordinadas no espaço social, a qual não é congruente com sua visão teórico-metodológica padrão sobre o tema.

Toda a teoria da violência simbólica de Bourdieu depende da ideia de uma "cumplicidade ontológica" entre habitus e campo em função da qual um ambiente estrutural atravessado por uma distribuição assimétrica de poder e de recursos é percebido e vivenciado como a ordem natural e evidente das coisas pelos atores nele imersos e por ele socializados. Mas não é apenas através de tal naturalização simbólico-cognitiva que a relação circular entre estruturas sociais e estruturas mentais leva à cumplicidade prática, demonstrada tanto por dominantes quanto por dominados, em relação à desigualdade nas "oportunidades de vida" (Weber) de 
indivíduos e grupos. A reprodução da dominação é tremendamente reforçada, em um nível motivacional, pelo fato de que condições sociais de existência distintas, isto é, restrições e oportunidades objetivas que influenciam diferencialmente atores assimetricamente posicionados no espaço social, são traduzidas pela socialização em orientações duráveis de conduta que pré-ajustam as aspiraçôes de tais agentes a uma antecipação prática, "intuitiva", de suas chances "realistas" na vida. A "situação existencial" (Mannheim) de uma classe ou grupo favorece a formação de um habitus dotado de um senso prático de antevisão do que é "possível" ou "impossível" para os ocupantes daquela posição no mundo social. Os membros de tais classes ou grupos fazem da necessidade uma virtude e excluem tacitamente do domínio do que é realisticamente desejável os próprios bens ou práticas aos quais eles já não têm acesso, de qualquer modo, em uma distribuição assimétrica de recursos vigente.

Como notou Andrew Sayer (2005, p. 31), esta noção teórica do amor fati exibido pelos dominados torna simplesmente ininteligíveis as expressões discursivas de insatisfação e sofrimento tão bem e comoventemente documentadas em $A$ miséria do mundo. Por definição, a dor e a frustração psicológicas derivadas do fato de se ter negadas as próprias pretensões a condições satisfatórias de existência, tais como conforto material ou reconhecimento social, podem ocorrer apenas se há um hiato entre desejos ou expectativas subjetivos, de um lado, e as experiências efetivas por que se passa no mundo social, de outro. $\mathrm{O}$ retrato bourdieusiano da subordinação das classes populares em $A$ distinção (2007, pp. 350-370) tem sido comumente criticado por negligenciar ou tornar inexplicáveis as diversas práticas ocasionais ou mesmo diárias de oposição e resistência levadas a cabo pelos dominados (Swartz, 1997, p. 174; Lovell, 2007, p. 85). Mas o que um livro como $A$ miséria do mundo também mostra é que, mesmo em situações em que não há, ao menos para todos os propósitos práticos, qualquer resistência à dominação estrutural e à distribuição desigual de recursos, a cumplicidade habitual dos dominados com a própria dominação que é observada no domínio da prática social pode coexistir com (e talvez até intensificar) uma experiência reflexiva, bastante consciente e, por vezes, discursivamente articulada de crítica aguda e rejeição dolorosa das próprias condiçôes sociais de existência ${ }^{8}$ (Sayer, 2005, p. 35). É necessário apenas sublinhar que Nietzsche utilizou a expressão latina para designar um estado de espírito feliz para que reconheçamos a pertinência de se distinguir entre o amor fati como cumplicidade prática e o amor fati como assentimento subjetivo. ${ }^{9}$ No nível de seu quadro teórico-metodológico de análise da vida social, Bourdieu poderia lidar com essa distinção apenas se houvesse mitigado sua pesada ênfase sobre o caráter tácito ou infraconsciente dos motores subjetivos da conduta humana, concedendo um espaço mais significativo à reflexividade do ator leigo em face tanto de seus ambientes sociais externos quanto de suas disposiçôes subjetivas internalizadas.

\section{Disposições habituais e deliberações reflexivas}

Verificamos que, em contextos e situações cuja frequência é bem maior do que parece supor Bourdieu, a consciência reflexiva do ator intervém entre as disposições práticas habituais e o contexto estrutural objetivo em que o agente está imerso como um fator mediador relativamente autônomo na determinação da ação. Deve-se ressaltar, entretanto, que, embora o habitus possa reinar absoluto como motor subjetivo da conduta em dados contextos sociopráticos (aqueles em que o mergulho na ação é tamanho que leva ao esquecimento de si os exemplos esportivos diletos de Bourdieu vêm à mente), a consciência reflexiva do agente nunca pode ter esse privilégio, pois sempre trabalha tendo como background irrefletido uma série de habilidades fundacionais do habitus, o que é evidenciado, por exemplo, pelo fato prosaico de que o exercício discursivo da consciência ou a formulação explícita de cursos possíveis de conduta estão vincados na operação tácita de regras sociolinguísticas de produção e interpretação de enunciados. Assim, recuperar a reflexividade do ator leigo não significa, de modo algum, fazer vista grossa às pertinentes críticas que Bourdieu dirige aos retratos excessivamente intelectualistas dos motores subjetivos da conduta 
presentes em outras paragens teórico-metodológicas, mas avançar no sentido de uma perspectiva não unilateral que seja capaz de perceber a ação humana como um produto contínuo da complexa interação intrassubjetiva (isto é, interna ao agente) entre disposiçōes práticas habituais e processos de deliberação reflexiva.

$\mathrm{O}$ exame da interação intrassubjetiva entre habitus e reflexividade requer, entretanto, o reconhecimento de que a "fronteira" entre essas duas instâncias é muito mais flutuante e permeável do que pensava Bourdieu, bem como de que a conduta socialmente situada transita cotidianamente entre uma e outra modalidade de motivação. Como notaram Hans Joas (1996) e Mitchell Aboulafia (1999, pp. 160-161), a conceituação da ação social em autores como George Herbert Mead e John Dewey, por exemplo, já trilhava uma frutífera via média entre um retrato anti-intelectualista de disposições infraconscientes que reproduziriam fluentemente interações rotineiras, de um lado, e uma pintura mais intelectualista da agência humana como movida pelo enfrentamento reflexivo de problemas conscientemente formulados em uma dada situação, de outro. Nessa perspectiva legada por certas versóes do pragmatismo, os seres humanos entregam-se a uma economia do pensamento reflexivo que prescinde de deliberações e cálculos conscientes nas situações em que suas propensões práticas habituais se ajustam, de modo infraconsciente e espontâneo, às exigências de seus ambientes. Apenas diante de maiores ou menores desajustes entre nossas intenções e intervenções práticas, de um lado, e os desafios agênticos colocados por nossos cenários de atuação, de outro, é que nossas faculdades criativas seriam requisitadas e se manifestariam sob a forma de uma busca reflexiva de soluções àqueles desafios. Tal perspectiva recebe uma formulação sistemática inegavelmente rica e sofisticada na pena de Joas em The creativity of action (1996). No entanto, embora a ideia de uma alternância contínua entre hábito e reflexão no curso da experiência cotidiana seja útil para combater os excessos de anti-intelectualismo presentes na teoria bourdieusiana do habitus, ela termina por deixar na sombra o caráter relativamente criativo das próprias condutas habituais, cuja natureza inventiva não de- pende necessariamente de deliberações reflexivas, mas pode estar incorporada à matriz mesma de respostas improvisadas do "senso prático" (Dalton, 2004 , p. 604). Caberia aqui uma distinção entre criatividade prática e criatividade reflexiva, já que o recurso bourdieusiano ao termo latino habitus expressa precisamente a tentativa de escapar às conotações behavioristas da noção de hábito como uma associação fixa e atomizada entre estímulo(s) e resposta(s), quando o que está em jogo no habitus é uma matriz gerativa que oferece ao agente uma capacidade genérica, versátil e inventiva de responder tacitamente a desafios situacionais contingentes.

Bourdieu adorava mobilizar ilustrações oriundas do esporte (1990a, p. 21) para questionar concepções excessivamente intelectualistas dos propulsores subjetivos da conduta social, as quais tendiam a projetar nas mentes dos atores, como causas empíricas de suas práticas, os modelos "escolásticos" por meio dos quais a "racionalidade" de seus comportamentos, isto é, seu ajuste pragmaticamente eficaz às demandas do contexto, podia ser reconstruída. Uma das formas pelas quais Bernard Lahire critica (corretamente) o acento exagerado de Bourdieu sobre o caráter tácito das motivações subjetivas da ação individual, com sua correlata negligência da importância motivacional de deliberações reflexivas na organização das práticas, é precisamente concebendo o retrato bourdieusiano do ator como fundado sobre uma generalização abusiva do "modelo esportivo da ação” (Lahire, 2002, p. 145).

No entanto, uma mirada na literatura sobre a aquisição de competências esportivas profissionais indica que o modelo esportivo do aprendizado não se aplica com perfeição sequer ao domínio do esporte. Ao contrário, o que especialistas na expert performance como o psicólogo sueco Anders Ericsson denominam "prática deliberada" (Ericsson e Charness, 1994) - fundada sobre um treinamento acompanhado de feedback sistemático (normalmente oferecido por um treinador habilitado) e especificamente projetada para o aperfeiçoamento das subcompetências envolvidas no alcance de expertise em determinada modalidade esportiva - constitui um exemplo quase paradigmático de interação mutuamente transformadora entre disposições habituais e deliberações reflexivas. Por um lado, espetáculos es- 
portivos de alto nível podem ser vistos, sim, como a prova viva de que o treinamento engendra nos seres humanos capacidades que podem ser mobilizadas, de maneira ao mesmo tempo espontânea e fluente, em respostas criativas e instantaneamente adequadas às injunçôes de um contexto - respostas que pareceriam resultar da consideração consciente de alternativas factíveis de ação se esta não fosse tornada impossível pela "urgência da prática". Por outro lado, qualquer etnografia que mergulhe nos bastidores de tais espetáculos verá também que a capacidade de operar com fluência e destreza nos cenários de prática urgente depende necessariamente da contraparte que ela parece esconder: uma lida lenta, dividida em fragmentos incessantemente repetidos e analisados, um treinamento que, longe de se abandonar a supostas autocorreções espontâneas do habitus do atleta, é pontuado a cada passo pelo retorno reflexivo do agente sobre os movimentos realizados e pela antecipação prospectiva dos movimentos a realizar - ambas as tarefas, aliás, realizadas com a orientação dialógica de um técnico imbuído do conhecimento perito acumulado a respeito daquele esporte.

As lições da análise da aquisição de competências esportivas acarretam implicações ainda mais abrangentes. No que toca ao aprendizado de modo geral, assim como o habitus constitui não um repertório de associações mecânicas e fixas do tipo estímulo/resposta propensas a gerar comportamentos repetidos, mas uma capacidade genérica e versátil de oferecer adaptações criativas (embora regradas), o modelo esportivo do progresso na fluência da ação utilizado por Bourdieu funda-se sobre o caráter tácita ou espontaneamente autocorretivo da prática. Além disso, nas poucas sugestôes que ele oferece para tornar translúcidas as caixas-pretas do processo de transmissão das primeiras estruturas do habitus no espaço familiar, o autor repele versões intelectualistas da socialização como imitação consciente de exemplares de conduta tomados explicitamente como tais e defende que a absorção de disposições se processa sobretudo através de um mimetismo inconsciente fundado na identificação global com gestos, atos, enunciados e atores e no aprendizado das "gramáticas gerativas" subjacentes a estes.
De modo irônico para um exterminador de dualismos sociocientíficos, a tentativa de estabelecer uma cisão bem definida entre habitus e consciência reflexiva no processo de socialização paga o preço de negligenciar o quanto nossas experiências de aprendizado, ao longo da vida, envolvem combinaçôes contínuas e frequentes entre incorporaçōes irrefletidas e orientações explícitas de conduta. Com efeito, em um texto que versa sobre Merleau-Ponty, mas está recheado de argumentos que poderiam valer muito bem para Bourdieu, Richard Shusterman mostrou que a possibilidade de transformação de princípios reflexivos conscientes em propensões automatizadas inconscientes vale até mesmo para o domínio predileto das diatribes anti-intelectualistas de Bourdieu (1990b, pp. 66-79), qual seja, o das "técnicas do corpo" (Mauss):

A misteriosa eficácia de nossa intencionalidade espontânea é certamente impressionante, mas não pode explicar sozinha todos os nossos poderes ordinários de movimento e percepção, discurso e pensamento. [...] Muitas coisas que agora fazemos (ou conhecemos) espontaneamente estiveram, em algum momento, abaixo do nosso repertório de performances irrefletidas. Elas tiveram de ser aprendidas [...]. Mas como? Um modo de explicar esse aprendizado seria pelo uso de vários tipos de representação (imagens, símbolos, proposições etc.) nos quais nossa consciência poderia se focar [...]. Mas Merleau-Ponty [assim como Bourdieu] parece demasiado crítico das representaçôes para aceitar essa opção. Em vez disso, ele explica tal aprendizado inteiramente em termos da aquisição automática de hábitos corporais por meio de condicionamentos motores irrefletidos ou sedimentação somática. [...] Mas há limites preocupantes à eficácia dos hábitos irrefletidos, mesmo no nível de ações corporais básicas. Irrefletidamente, podemos adquirir maus hábitos tão facilmente quanto bons. [...] Uma vez que maus hábitos sejam adquiridos, como os corrigimos? Não podemos simplesmente nos entregar ao hábito sedimentado para corrigi-los, já que os hábitos sedimentados são precisamente o que está errado. [...] É por isso que 
várias disciplinas do corpo tipicamente envolvem representações e concentraçôes somáticas autoconscientes para corrigir as nossas falhas de autopercepção e uso do corpo (Shusterman, 2005, pp. 164-165).

É gratificante perceber que o próprio Bourdieu veio a falar tardiamente em entrelaçamentos situacionais entre orientaçôes reflexivas e manobras práticas:

[...] as improvisações do pianista ou as ditas figuras livres do ginasta nunca acontecem sem [...] uma certa forma de pensamento ou mesmo de reflexão prática, reflexão em situação e ação que se faz necessária para avaliar em cima do lance a ação ou o gesto realizado e assim poder corrigir uma má posição do corpo, retomar um movimento imperfeito (a mesma coisa ocorre, a fortiori, em condutas de aprendizagem (Bourdieu, 2001c, p. 198, grifo do autor).

De fato, a proposta inteira da sociologia reflexiva será inócua se não pressupor que podemos utilizar a reflexividade, em conluio com o corpo, para corrigir maus hábitos - ou até mesmo maus habitus.

\section{Notas crítico-reconstrutivas}

A crítica supradelineada do neo-objetivismo na teoria da prática de Bourdieu foi concebida como parte de um esforço teórico-metodológico reconstrutivo cujo propósito é o de aproximá-la (mesmo que isso signifique necessariamente dissolver, em maior ou menor medida, sua identidade específica como "a teoria de Bourdieu") de um tratamento sintético mais satisfatório da relação de interdependência causal entre a ação individual subjetivamente propelida e as propriedades estruturais, institucionais e culturais das formaçôes societárias em que os atores estão imersos. Tal tarefa de crítica e reconstrução depende, entretanto, de um conjunto de reformulaçōes concomitantes em outras dimensões centrais da praxiologia bourdieusiana, reformulaçôes que não posso defender em detalhe no presente contexto, mas que elencarei de modo breve:

a) Neo-objetivismo e pancratismo: a quase-absolutização do senso prático como motor da ação também tem como consequência uma espécie de "reducionismo do poder" (Giddens, 1998, p.323) ou "pancratismo" (Merquior, 1985, p.176), expressóes cunhadas em críticas dirigidas, na verdade, a um colega de Bourdieu no Collège de France: Michel Foucault. Vimos que Bourdieu defende a tese de que o habitus engendra práticas e representações "que podem ser objetivamente 'reguladas' e 'regulares' sem serem produto da obediência a regras, objetivamente adaptadas a seu fim sem supor a intenção consciente dos fins" (Bourdieu, 1983a, p. 61), utilizando tal tese para reduzir a heterogeneidade motivacional da ação a estratégias de conquista ou manutenção de poder/capital simbólico, ainda que sempre faça questão de destacar que se refere a estratégias historicamente específicas de luta por formas historicamente específicas de poder associadas a campos historicamente específicos. Sua economia geral das práticas multiplica as possibilidades de bens simbólicos e espécies de interesses perseguidos em espaços sócio-históricos particulares, ao mesmo tempo em que caracteriza, entretanto, a luta pela maximização do capital simbólico per se, do "reconhecimento" ou distinção social, como o motor fundamental da vida humana em sociedade. Como demonstram as críticas de Giddens e Merquior ao método genealógico de Foucault, as quais poderiam valer, mutatis mutandis, para o próprio Bourdieu, sublinhar corretamente que todo processo social está permeado de relações de poder não significa subscrever a tese de que a busca estratégica de poder tem de ser concebida como o traço essencialmente definidor e/ou como explanans último ou fundamental da geração da conduta individual e da reprodução/transformação de estruturas sociais.

A orientação socioteórica "pancrática" leva Bourdieu a: 1) abolir a distinção entre motores estratégicos e motores normativos da conduta huma- 
na, subsumindo os últimos nos primeiros (Bourdieu e Wacquant, 1992, p. 139); 2) conceber a dinâmica do reconhecimento social apenas como um jogo de soma-zero, o que explica as implicações pessimistas e hiperagonísticas de sua visão do mundo social, em que a valorização simbólica depende necessariamente de uma contraparte desvalorizada - "todo sagrado tem o seu profano complementar, toda distinção produz sua vulgaridade e a concorrência pela existência social conhecida e reconhecida, que subtrai à insignificância, é uma luta de morte pela vida e pela morte simbólicas" (Bourdieu, 1988a, p. 56; Peters, 2012). Ainda que eu não concorde com o argumento, avançado por Sayer (2005, pp. 40-41), de que o uso bourdieusiano de conceitos motivacionais oriundos da economia falha em capturar a intensidade existencial ou força afetiva do engajamento dos atores com os jogos do mundo social (Sayer parece esquecer, por exemplo, o influxo freudiano na noção de investimento), certamente subscrevo sua visão de que tal uso acarreta um tratamento deficiente das dimensões morais da conduta humana, sobretudo ao tornar impossível explicar situaçôes em que os agentes sacrificam o autointeresse instrumental que possuem na acumulação e/ou manutenção de seu status social ou capital simbólico em favor de um compromisso com valores. Dado que as teorias são subdeterminadas pelos fatos, sempre é possível enquadrar intelectualmente os fenômenos prima facie normativos de maneira tal que eles se conformem à "lei do autointeresse" (Bourdieu, 1990b, p. 57). Embora o conceito de estratégia inconsciente seja heuristicamente valioso em uma variedade de contextos, ele é particularmente propenso a ser mobilizado de forma abusiva como uma ferramenta explanatória capaz de "salvar" a lei do autointeresse de quaisquer refutações empíricas.

A subsunção, em Bourdieu, da diversidade motivacional da conduta humana a estratégias de consecução ou manutenção de múltiplas formas de poder/capital, mesmo nos casos de comportamentos que não são subjetivamente vivenciados como tais (o que levou Alexander [1995, p. 152] a qualificar o conceito de "estratégia inconsciente" como um oximoro), já foi tão criticada que talvez não precisemos nos alongar aqui. É suficiente di- zer que, como reza a frase de Mao que ele gostava de citar, o bastão foi torcido em demasia para um dos lados da questão. Por um lado, não há dúvida quanto ao valor de seu esforço incansável "para evitar a sentimentalidade" (Idem, ibidem; ver também Honneth, 1995), fundamental para qualquer um que almeje a uma compreensão realista, ainda que desencantadora, do mundo social, sobretudo no que toca à sua "face feia" (Dahrendorf), para Bourdieu freqüentemente escondida sob o véu suave da violência simbólica. Por outro lado, em virtude de sua visão agonística do universo societário como cenário de infinda competição estratégica, o sociólogo francês vai longe demais em sua tendência a caracterizar toda ação normativamente orientada como uma busca utilitária velada por acumulação de poder/capital, fechando a porta para a teorização de ações genuinamente orientadas por normas e valores morais e capazes de escapar à "água gelada do cálculo egoísta [mesmo que inconsciente]”, como diria Marx..$^{10}$ De modo similar, mesmo autores que também admitem que os seres humanos anseiam universalmente pelo reconhecimento social podem problematizar, ainda sim, a visão segundo a qual tais processos só poderiam ocorrer nos jogos encarniçadamente competitivos de soma-zero que acontecem em campos sociais.

b) A interação intersubjetiva - relacionismo $e$ situacionismo metodológicos: a praxiologia estrutural bourdieusiana tem como alicerces uma ontologia e epistemologia relacionais (Bourdieu, 1990b, p. 284; Vandenberghe, 2010, cap. 1), em contraposição à visão que Bourdieu, apoiando-se em autores tão diversos quanto Marx, Durkheim, Cassirer, Lewin, Elias, Sapir, Jakobson, Dumézil, Lévi-Strauss e outros, denomina substancialista. Com efeito, o relacionismo metodológico calcado no conceito de campo é um dos caminhos através dos quais Bourdieu identifica as lacunas fundamentais do situacionismo metodológico de determinadas abordagens microssociológicas, como o interacionismo simbólico e a linha etnometodológica da análise conversacional. Os proponentes destas julgam ser possível explicar as práticas desempenhadas em uma interação 
face-a-face apenas pela referência às propriedades diretamente inscritas na ocasião interativa, sem se dar conta de que "a verdade da interação nunca jaz inteiramente na interação" (Bourdieu, 1990b, p. 291), isto é, de que a estrutura da conjuntura momentânea da interação é poderosamente condicionada pela inserção dos agentes em toda uma série de coordenadas posicionais próprias de estruturas transcendentes à microssituação interativa que elas informam.

No entanto, embora seja importante reconhecer o papel de influências sociais macroscópicas ou trans-situacionais sobre os contextos particulares de interação, parece-me que Bourdieu novamente "torce demais o bastão para o outro lado", tendendo a tratar as "estruturas conjunturais como simples epifenômenos da estrutura objetiva" (Vandenberghe, 2006, p. 191). Por um lado, o sociólogo francês tem razão em criticar ocasionalismos metodológicos radicais quando sublinha que

[...] se um francês conversa com um argelino, ou um americano negro conversa com um Wasp, não são duas pessoas que conversam, mas a história colonial em sua inteireza, ou toda a história da subjugação econômica, política e cultural de negros (ou mulheres, trabalhadores, minorias etc.) nos Estados Unidos (Bourdieu e Wacquant, 1992, p. 144).

Por outro lado, o fato de que interações particulares são causalmente condicionadas por tais fatores macro-históricos não significa que possamos simplesmente deduzir quais serão os atributos fundamentais de toda e qualquer interação de um mesmo "tipo"; ou, em outros termos, que não haja qualquer margem substancial de variação entre diferentes encontros interativos que são, para todos os propósitos da macrossociologia estrutural, "idênticos". Naturalmente, não há espaço aqui para avaliar em detalhe os méritos e deméritos analíticos de caminhos ascendentes (bottom-up) ou descendentes (top-down) de "solução" do problema do "micro-macro link" (Alexander e Giesen, 1987), mas podemos, ao menos, defender que o que precisamos é de uma visão mais matizada e dialética que seja capaz de escapar tanto ao relacionismo estrutural que ignora a autonomia relativa da "ordem da interação" (Mouzelis, 1995, p. 111) quanto ao situacionismo ou ocasionalismo radicais de certas abordagens que tomam os contextos locais de ação e interação como microcosmos herméticos.

c) Os limites da aplicabilidade do conceito de campo para lidar com os contextos sociais da ação individual: ainda que a relação habitus/campo seja frequentemente utilizada para revestir o conteúdo do relacionamento entre agência $e$ estrutura no pensamento de Bourdieu, é necessário reconhecer a existência de uma espécie de "assimetria analítica" entre as duas categorias, pelo fato de que a primeira é metodologicamente aplicável ao estudo de um espectro bem mais amplo de contextos sócio-históricos do que a segunda (Calhoun, 1993, p. 67). O próprio Bourdieu reconhece o caráter analiticamente mais circunscrito do conceito de campo ao relacioná-lo explicitamente ao diagnóstico sociológico da modernidade, isto é, à tese amplamente defendida (ao menos, desde Durkheim) de que a constelação de instituições modernas tem como um de seus traços estruturais historicamente mais característicos a diferenciação de seu arranjo social total em distintas esferas de atividade relativamente autônomas. Por outro lado, ele desliza para a falácia da generalização abusiva nos momentos em que toma, explícita ou implicitamente, o conceito de campo como a única, ou ao menos a mais importante, ferramenta conceitual para lidar com os contextos estruturais das práticas dos agentes individuais. Conquanto seja um conceito fundamental para lidar com certas esferas específicas de atividade muito características do mundo social contemporâneo (espaços de atuação profissional e/ou pública nos quais há uma luta por obtenção de prestígio/capital simbólico), ele é, como vem enfatizando Bernard Lahire (2002, p. 35), obviamente insuficiente para a compreensão das condutas seja da massa de atores que não participam desses jogos de prestígio, seja das açōes que aqueles envolvidos nas lutas de um campo desempenham quando estão fora dele. ${ }^{11}$ 
No que toca ao problema da aplicabilidade analítica a diferentes contextos sócio-históricos, sobretudo àqueles não modernos, isto é, pouco diferenciados institucionalmente, creio que seria mais adequado trabalhar com conceitos mais abstratos para designar as redes de relações cooperativas e/ou conflitivas nas quais os atores estão imersos, conceitos tais como a noção giddensiana de sistemas sociais (Giddens, 2003) ou a ideia eliasiana de "figuração". ${ }^{12}$ Por fim, movendo-nos do passado pré-moderno para o presente neo ou pós-moderno, bem como para um presumido futuro próximo, não é preciso ser latouriano ou deleuziano para reconhecer que o conceito de campo, embora seja tomado por Bourdieu como referente a uma realidade perpetuamente em movimento e historicamente atualizada de modo contínuo por suas "partículas" constituintes (inclusive no que tange a seus limites formal ou informalmente estabelecidos), possui, entretanto, uma conotação de relativo "fechamento" e coerência (fronteiras bem demarcadas, certa estabilidade etc.) que parece inadequada para captar a enorme multiplexidade, flexibilidade, fluidez, contingência e instabilidade das relações sociais contemporâneas em tempos de globalização acentuada e capitalismo mundial pós-fordista em expansão. Não deixa de ser sintomático do atual Zeitgeist, nesse sentido, que a sociologia francesa pós-bourdieusiana tenha jogado as "redes e rizomas" contra as "estruturas", substituindo as "relaçōes estruturais entre posiçôes" pelas "relaçōes intersubjetivas que tecem redes" (Vandenberghe, 2006, p. 31).

\section{Conclusão}

Recentemente deparei-me com uma coletânea de ensaios de Bobbio (lúcidos, como de costume) sobre Marx e o(s) marxismo(s) intitulada Nem com Marx, nem contra Marx (2006). Embora este título aponte saudavelmente para a necessidade de escapar à alternativa maniqueísta entre a adoração e a ojeriza diante da obra marxiana, não pude deixar de pensar que Bourdieu, de resto em pleno acordo quanto à necessidade de superação dessa alternativa entre posições unilaterais (superação de alternativas dicotômicas era com ele mesmo!), sem dúvida julgaria que um título mais apropriado para um projeto dessa natureza seria "Com Marx e contra Marx" (ver, por exemplo, Bourdieu, 1988c, p. 780). Com efeito, ainda que o sociólogo francês fosse, por vezes, irritantemente rabugento diante das apreciações críticas de seu trabalho, a fidelidade ao seu espírito, mais do que à sua letra, reclama que o leiamos seguindo o exemplo que ele mesmo oferece em seu trato intelectual não apenas da obra de Marx como também de Durkheim, Weber, Husserl, Lévi-Strauss e tutti quanti. O presente trabalho constitui, nesse sentido, parte de um esforço teórico-metodológico para pensar "com Bourdieu contra Bourdieu" (Corcuff, 2003) de modo a ir além de Bourdieu, no que já tem sido, de toda forma, a diretriz seguida por vários de seus críticos mais perspicazes, como Hans Herbert Kogler (1997), Bernard Lahire (2002) e Frédéric Vandenberghe (2010). Como disse um sábio filósofo grego, nascido (e aqui nossas associações mnemônicas espontâneas tendem a ser enganosas) muito depois de Cristo: "Honrar um pensador não é elogiá-lo, nem mesmo interpretá-lo, mas discutir sua obra, mantendo-o, dessa forma, vivo e demonstrando, em ato, que ele desafia o tempo e mantém sua relevância” (Castoriadis).

\section{Notas}

1 Como a definição apresentada no início do texto permite entrever, o próprio espaço das classes sociais pode, na verdade, ser tomado como um campo.

2 Veremos mais adiante que essa problemática é central em diversas discussões críticas quanto ao sucesso do projeto teórico-sintético de Bourdieu, em particular no que tange à alcunha de neo-objetivista comumente dirigida contra ele. Além disso, a questão também é fulcral para a compreensão das dessemelhanças entre o seu quadro teórico-metodológico e a (similar sob outros aspectos) teoria da estruturação de Giddens, a qual, a despeito de não pretender reduzir a ciência social à sua dimensão interpretativa, postula para esta um ponto de partida necessariamente hermenêutico (Giddens, 1978, p. 170; para uma análise mais detalhada da perspectiva giddensiana, ver Peters, 2011c; no prelo). 
3 Não podemos explorar esse ponto em detalhe aqui (ver Peters, 2012), mas esta referência às lutas históricas deriva do fato de que Bourdieu trabalha com uma concepção fundamentalmente conflitual do universo social. $\mathrm{Na}$ sua concepção, relaçōes sociais são sempre relações de força: toda formação societária é pensada por ele como um espaço estruturado de relações objetivas de poder entre indivíduos el ou grupos situados em posiçôes diferenciais definidas conforme uma distribuição desigual de recursos materiais e simbólicos (ou formas de capital, que podem ser as mais diversas).

4 Rendendo-me ao uso corrente, e com o perdão dos leitores ortodoxos, continuarei, daqui em diante, a falar dos habitus, ao invés dos habiti.

5 Poder-se-ia falar, talvez, de "micro-histereses" ordinárias.

6 Considero difícil não ver, na autoanálise do nosso herói, também uma autobiografia - aliás, com momentos comoventes. Graças à escolha da frase "Isto não é uma autobiografia” para epígrafe de seu livro (2005, p. 36), Bourdieu conseguiu produzir um caso raro de autobiografia não autorizada.

7 Da clássica inscrição no templo de Delfos: "conhece-te a ti mesmo".

8 Uma condição existencial que pode efetivamente evoluir para uma resistência política ativa, como no caso do movimento dos desempregados na França, do qual Bourdieu foi um defensor entusiástico e que ele veio a descrever, utilizando-se de uma metáfora religiosa que traía uma confissão dos limites de seu modelo teórico, como um "milagre social" (Bourdieu, 1998, p. 128).

9 Quando se trata de lidar com o hiato entre desejos e oportunidades, também vale a pena notar que o teorema da adaptação das expectativas às chances conta apenas metade da história: a "tensão entre expectativas e possibilidades não precisa sempre resultar em resignação, aceitação e recusa do que é negado. Ela também pode resultar no anseio pelo que é negado ao ator [...]. Dada a impiedosa sedução das mercadorias, a glorificação do avanço educacional e do sucesso econômico, a pressão para se conformar ao gênero e para ser popular e atraente, acompanhadas pela insegurança econômica, pela anomia e pela solidão, não surpreende que o anseio não satisfeito possa ser tão poderoso" (Sayer, 2005, p. 35). Um modelo complexo da subjetividade que envolva tanto disposiçôes habituais quanto deliberações reflexivas pode acomodar situações em que a cumplicidade comportamental e a resignação, para todos os efeitos práticos, coexistem com a inflação reflexiva dos desejos por bens ou objetivos extremamente distantes ou praticamente inacessíveis - desejos que também podem encontrar satisfação compensatória no domínio da fantasia.

10 O hábito bourdieusiano de buscar os interesses estratégicos subjacentes a valores e normas faz-me lembrar do curso imaginário de verão bolado por Woody Allen: "O imperativo categórico - e seis maneiras de fazê-lo funcionar a seu favor".

11 O próprio fato de que Bourdieu tende a pensar o reconhecimento social como resultado de um jogo competitivo de soma-zero pode ser devido a uma generalização infundada da noção de campo para designar os contextos sociais em que os agentes individuais buscam acumular capital simbólico.

12 Naturalmente, embora todo campo (no sentido de Bourdieu) constitua um sistema social (no sentido de Giddens) ou figuração (no sentido de Elias), nem todo sistema social ou figuração constitui um campo.

\section{BIBLIOGRAFIA}

ABOULAFIA, Mitchell. (1999), "A (neo)American in Paris: Bourdieu, Mead, and pragmatism", in Richard Shusterman (org.), Bourdieu: a critical reader, Oxford, Blackwell.

ALEXANDER, Jeffrey. (1995), Fin de siècle social theory: relativism, reduction and the problem of reason. Londres, Verso.

ALEXANDER, Jeffrey \& GIESEN, Bernard. (1987), "From reduction to linkage: the long view of the micro-macro debate", in Jeffrey Alexander et al. (orgs.), The micro-macro link, Berkeley/Los Angeles, University of California Press.

ARCHER, Margaret. (2003), Structure, agency and the internal conversation. Cambridge, Cambridge University Press. . (2007), Making our way through the world. Cambridge, Cambridge University Press.

BOBBIO, Norberto. (2006), Nem com Marx, nem contra Marx. São Paulo, Unesp.

BOURDIEU, Pierre. (1979a), Outline of a theory of practice. Cambridge, Cambridge University Press. 
. (1979B), O desencantamento do mundo: estruturas econômicas e estruturas temporais. São Paulo, Perspectiva. . (1983A), Questôes de sociologia. Rio de Janeiro, Marco Zero. . (1983B), Sociologia. Org. Renato Ortiz. São Paulo, Ática (col. Grandes Cientistas Sociais).

Ática.

(1988A), Lições da aula. São Paulo, . (1988B), Homo academicus. Stanford, Stanford University Press.

. (1988C), "Vive la crise! For heterodoxy in social science". Theory and Society, 17: 773-777.

. (1989), La noblesse d'Etat: grandes écoles et sprit de corps. Paris, Editions de Minuit.

. (1990a), Coisas ditas. São Paulo, Brasiliense.

. (1990b), The logic of practice. Stanford, Stanford University Press.

(1990c), In other words. Stanford, Stanford University Press.

(org.). (1997), A miséria do mundo. Petrópolis, Vozes.

(1998), Contrafogos: táticas para enfrentar a invasão neoliberal. Rio de Janeiro, Jorge Zahar, 1998.

(1999), A dominação masculina. Rio de Janeiro, Bertrand Brasil.

. (2000), A profissão de sociólogo. Petrópolis, Vozes, 2000.

. (2001a), O poder simbólico. Rio de Janeiro, Bertrand Brasil.

- (2001b), A economia das trocas simbólicas. São Paulo, Perspectiva.

(2001c), Meditaçôes pascalianas. Rio de Janeiro, Bertrand Brasil.

. (2005), Esboço de auto-análise. São Paulo, Companhia das Letras.

(2007), A distinção: crítica social do julgamento. São Paulo/Porto Alegre, Edusp/ Zouk, 2007.

BOURDIEU, Pierre \& PASSERON, Jean-Claude. (1975), A reprodução: elementos para uma teoria do sistema de ensino. Rio de janeiro, Francisco Alves.
BOURDIEU, Pierre \& WACQUANT, Loic. (1992), An invitation to reflexive sociology. Chicago, University of Chicago Press.

CALHOUN, Craig. (1993), "Habitus, field and capital: the question of historical specificity", in Craig Calhoun et al. (orgs.), Bourdieu: critical perspectives, Chicago, Polity Press. . (2003), "Pierre Bourdieu", in George Ritzer (org.), The blackwell companion to major contemporary social theorists, Cambridge, MA, Blackwell.

COHEN, Ira. (1999), “Teoria da estruturação e práxis social", in A. Giddens e Jonathan Turner (orgs.), Teoria social hoje, São Paulo, Editora da Unesp.

COHN, Gabriel. (1979), Crítica e resignação: fundamentos da sociologia de Max Weber. São Paulo, T. A. Queiroz.

CORCUFF, Phillipe. (2003), Bourdieu autrement: fragilités d'un sociologue de combat. Paris, Textuel.

CROSSLEY, Nick. (2001), "The phenomenological habitus and its construction". Theory and Society. 30 (1): 81-120.

DALTON, Benjamin. (2004), "Habitus, creativity, and the social products of creative action: revising Joas, incorporating Bourdieu”. Sociological Theory, 22 (4): 603-622.

ELDER-VASS, Dave. (2007), “Reconciling Archer and Bourdieu in an emergentist theory of action”. Sociological Theory, 25 (4): 325-346.

ELIAS, Norbert. (1994), A sociedade dos individuos. Rio de Janeiro, Jorge Zahar, 1994.

ERICSSON, Anders \& CHARNESS, Neil. (1994), "Expert performance: its structure and acquisition”. American Psychologist, 49 (8), pp. 725-747.

FRANGIE, Samer. (2009). "Bourdieu's reflexive politics: socio-analysis, biography and self-creation". European Journal of Social Theory, 12 (2): 213-229.

GIDDENS, Anthony. (1978), Novas regras do método sociológico. Rio de Janeiro, Zahar. (1979), Central problems in social theory. Londres, Macmillan. (1993), A transformação da intimidade. São Paulo, Editora da Unesp. 
(1998), Politica, sociologia e teoria so-

cial. São Paulo, Editora da Unesp.

. (2003), A constituição da sociedade.

São Paulo, Martins Fontes.

HADOT, Pierre. (1995), Philosophy as a way of life: spiritual exercises from Socrates to Foucault. Princeton, Princeton University Press. . (2004), O que é a filosofia antiga?. São Paulo, Loyola.

HONNETH, Axel. (1995), The fragmented world of the social. Nova York, State University of New York Press.

JOAS, Hans. (1996), The creativity of action. Cambridge, Polity Press.

KOGLER, Hans Herbert. (1997), "Alienation as epistemological source: reflexivity and social background after Mannheim and Bourdieu". Social Epistemology, 11 (2): 297-320.

LAHIRE, Bernard. (2002), O homem plural: os determinantes da ação. Petrópolis, Vozes.

LOVELL, Terry. (2007), "Nancy Fraser's integrated theory of justice: a 'sociologically rich' model for a global capitalist era?", in Terry Lovell (org.), (Mis)recognition, social inequality and social justice: Pierre Bourdieu and Nancy Fraser, Londres, Routledge.

MARX, Karl. (2000), Manifesto do partido comunista \& Teses sobre Feuerbach. São Paulo, Martin Claret.

MERQUIOR, José Guilherme. (1981), As ideias e as formas. Rio de Janeiro, Nova Fronteira. (1985), Foucault; ou o niilismo de cátedra. Rio de Janeiro, Nova Fronteira.

MICELI, Sergio. (2001), "Introdução", in Pierre Bourdieu, A economia das trocas simbólicas, São Paulo, Perspectiva.

MONTAIGNE, Michel Eyquem de. (1985), Ensaios. Brasília, Editora da UnB/Hucitec, vol. 1.

MOUZELIS, Nicos. (1995), Sociological theory: what went wrong?. Londres/Nova York, Routledge.

ORTIZ, Renato. (1983), "Introdução", in Pierre Bourdieu, Sociologia. Org. Renato Ortiz, São Paulo, Ática (col. Grandes Cientistas Sociais).

PARKER, John. (2000), Structuration. Philadelphia, Open University Press.
PETERS, Gabriel. (2010), "Humano, demasiado mundano: a teoria do habitus em retrospecto". Teoria \& Sociedade, 18 (1): 8-37.

. (2011A), "Admirável senso comum: agência e estrutura na sociologia fenomenológica”. Ciências Sociais Unisinos, 47 (1): 85-97.

. (2011B), "Explicacão, compreensão e determinismo na sociologia de Pierre Bourdieu". Estudos de Sociologia, 2 (17): s. p.

. (2011C), "A praxiologia culturalista de Anthony Giddens". Teoria \& Pesquisa: Revista de Ciência Politica, 20 (1): 123-147.

. (2012). "O social entre o céu e o inferno: a antropologia filosófica de Pierre Bourdieu”. Tempo Social, 24 (1): 229-261.

. (no prelo), "Agência, estrutura e práxis: uma leitura dialógica da teoria da estruturação de Anthony Giddens”. Teoria \& Sociedade.

SAYER, Andrew. (2005), The moral significance of class. Cambridge, Cambridge University Press.

SCHUTZ, Alfred. (1962), Collected Papers I: the problem of social reality. The Hague, Martinus Nijhoff.

SHUSTERMAN, Richard. (2005), "The silent, limping body of philosophy", in Taylor Carman e Mark Hansen, The Cambridge Companion to Merleau-Ponty. Cambridge, Cambridge University Press.

SIBEON, Roger. (2004), Rethinking social theory. Londres, Sage.

SWARTZ, David. (1997), Culture and power: the sociology of Pierre Bourdieu. Chicago, University of Chicago Press.

VANDENBERGHE, Frédéric. (2006), Complexités du posthumanisme: trois essais dialectiques sur la sociologie de Bruno Latour. Paris, L'Harmattan. . (2010), Teoria social realista: um diálogo franco-britânico. Belo Horizonte, Editora da UFMG.

WACQUANT, Loïc. (1992), "Toward a social praxeology: the structure and logic of Bourdieu's Sociology", in P. Bourdieu e L. Wacquant, $A n$ invitation to reflexive sociology. Chicago, University of Chicago Press. 


\section{HABITUS, REFLEXIVIDADE E NEO-OBJETIVISMO NA TEORIA DA PRÁTICA DE PIERRE BOURDIEU}

\section{Gabriel Peters}

Palavras-chave: Pierre Bourdieu; Teoria da prática; Neo-objetivismo; Habitus; Reflexividade.

A tentativa de superação da dicotomia subjetivismo/objetivismo está na raiz da perspectiva praxiológica de Bourdieu, cujo cerne é a relação dialética entre condutas individuais subjetivamente propelidas por disposiçōes integradas em um habitus, de um lado, e estruturas objetivas ou "campos" de relaçôes entre agentes diferencialmente posicionados e empoderados, de outro. No entanto, esta abordagem tem sido retratada por críticos como uma versão sofisticada de neo-objetivismo e não como uma teoria sintética satisfatória da relação agência/ estrutura. $\mathrm{O}$ artigo avalia o sentido desta crítica, argumentando que ela é parcialmente justificada e defendendo a tese de que a principal fonte do neo-objetivismo na obra de Bourdieu deriva de sua ênfase, valiosa porém unilateral, sobre o caráter tácito ou "pré-reflexivo" da operação do habitus, a qual leva-o a uma teorização negligente quanto à significação agêntica da consciência reflexiva do ator. Com base nesse diagnóstico, o texto delineia, por fim, alguns percursos teóricos pelos quais o esquema analítico bourdieusiano pode ser orientado para um tratamento mais genuinamente dialético da interdependência causal entre ações individuais e estruturas sociais.

\section{HABITUS, REFLEXIVITY AND NEO-OBJECTIVISM IN PIERRE BOURDIEU'S THEORY OF PRACTICE}

\section{Gabriel Peters}

Keywords: Pierre Bourdieu; Theory of practice; Neo-objectivism; Habitus; Reflexivity.

The attempt to overcome the subjectivism/objectivism dichotomy is at the root of Bourdieu's praxeological perspective, whose core is the dialectical relation between individual conducts that are subjectively propelled by dispositions integrated into a habitus, on the one hand, and objective structures or "fields" of relations between differentially positioned and empowered agents, on the other. However, this approach has been portrayed by critics as a sophisticated version of neo-objectivism, rather than a satisfactorily synthetic theory of the agency/structure relationship. The article evaluates this critique, defending that the main source of neo-objectivism in Bourdieu's oeuvre stems from his valuable, but unilateral, emphasis on the tacit or "pre-reflexive" character of the operation of the habitus, which leads him to a theorization that neglects the agentic significance of the actor's reflexive consciousness. Finally, based on this diagnosis, the paper delineates some theoretical paths through which Bourdieu's analytical scheme may be inflected towards a more genuinely dialectical treatment of the causal interdependence between individual actions and social structures.

\section{HABITUS, RÉFLEXIVITÉ ET NÉO-OBJECTIVISME DANS LA THÉORIE DE LA PRATIQUE DE PIERRE BOURDIEU}

\section{Gabriel Peters}

Mots-clés: Pierre Bourdieu; Théorie de la pratique; Néo-objectivisme; Habitus; Réflexivité.

L'effort en vue de surmonter l'opposition entre le subjectivisme et l'objectivisme est à la racine de la perspective praxéologique de Bourdieu, dont le noyau est la relation dialectique entre, d'une part, des conduites individuelles subjectivement propulsées par des dispositions intégrées dans un habitus et, d'autre part, des structures objectives ou " champs " de relations entre des agents avec des positions différentes et des pouvoirs inégaux. Les critiques ont, néanmoins, désigné cette théorie comme une version sophistiquée du néo-objectivisme et non pas comme une théorie synthétique réussie de la relation entre action et structure. Larticle propose une évaluation du sens de cette critique et démontre qu'elle est partiellement justifiée. Il soutient la thèse selon laquelle la principale source du néo-objectivisme dans l'œuvre de Bourdieu provient principalement de l'accent qu'il porte sur la nature tacite ou "préréflexive " de l'opération de l'habitus, ce qui le conduit à une théorisation qui néglige la signification de la conscience réflexive de l'acteur pour l'action. Grâce à ce diagnostic, le texte indique quelques parcours techniques grâce auxquels le schéma analytique de Bourdieu peut être dirigé vers un traitement véritablement dialectique de l'interdépendance causale entre les actions individuelles et les structures sociales. 